Florida A\&M University College of Law

Scholarly Commons @ FAMU Law

Apprendi Land Becomes Bizarro World: Policy Nullification and Other Surreal Doctrines in the New Constitutional Law of Sentencing

Benjamin Priester

Follow this and additional works at: https://commons.law.famu.edu/faculty-research

Part of the Criminal Law Commons, and the Jurisprudence Commons 


\title{
APPRENDI LAND BECOMES BIZARRO WORLD: "POLICY NULLIFICATION" AND OTHER SURREAL DOCTRINES IN THE NEW CONSTITUTIONAL LAW OF SENTENCING
}

\author{
Benjamin J. Priester*
}

\section{INTRODUCTION}

Imagine a final exam essay answer in constitutional law premised upon the following doctrinal principles: (i) identical findings of fact that produce identical effects on the outcome of a decision should sometimes be constitutional and should sometimes be unconstitutional based on formalistic doctrinal lines unrelated to the substantive merits of the issue being decided; (ii) decision-makers should preferably give vague explanations grounded in moral philosophy rather than specific explanations connected to particular findings; (iii) appellate review of trial court decision-making is unconstitutional; and (iv) courts are entitled to substitute their own policy preferences for those enacted by the legislature on questions of non-constitutional law. In fact, it is probably unconstitutional to enact legislation expressly compelling courts to follow the legislature's non-constitutional policy preferences.

Naturally, we might expect such an exam answer to receive an $F$. But if the exam question involved the United States Supreme Court's new constitutional law of sentencing, then the student has probably earned an A. Welcome to Apprendi Land-which has now become Bizarro World. ${ }^{1}$ How

* Associate Dean of Faculty Development and Professor of Law, Florida Coastal School of Law.

1. The term Apprendi Land was coined by Justice Scalia in a characteristic snark. See Ring v. Arizona, 536 U.S. 584, 613 (2002) (Scalia, J., concurring) ("Concisely put, Justice Breyer is on the wrong flight; he should either get off before the doors close, or buy a ticket to Apprendi-land."). The term was later 
did we get to this point? ${ }^{2}$

Little more than a decade ago, if you had asked any criminal procedure professor, criminal law practitioner, or judge to describe the doctrines of constitutional law that specifically govern the sentencing of a convicted criminal defendant, the answer would have been simple and reflexive: leaving aside the myriad of special rules for capital cases, there were not any. ${ }^{3}$ Of course, the basic, general principles of constitutional law applied to sentencing and ensured, for example, that the sentencing judge was neutral and unbiased as a matter of procedural due process, or that the sentence imposed was not motivated by an impermissible classification of race or sex as a matter of equal protection. ${ }^{4}$ But there was no constitutional law of sentencing as such, no set of doctrines specifically directed at either the procedure or the substance

fired back at him by Justice O'Connor. See Blakely v. Washington, 542 U.S. 296,314 (2004) (O'Connor, J., dissenting) ("It is thus of little moment that the majority does not expressly declare guidelines schemes unconstitutional for, as residents of 'Apprendi-land' are fond of saying, the relevant inquiry is one not of form, but of effect."). Bizarro World was a concept introduced in the Superman comics of the 1960s: it is a planet where everything is backwards to the way it is on Earth. See generally Bizarro World, WIKIPEDIA: THE FREE ENCYCLOPEDIA, http://en.wikipedia.org/wiki/Bizarro_World (last visited August 9, 2010). The 1990 s sitcom Seinfeld famously premised an episode in its eighth season as homage to this concept. See The Bizarro Jerry, WIKIPEDIA: THE FREE ENCYCLOPEDIA, http://en.wikipedia.org/wiki/The_Bizarro_Jerry (last visited August 9, 2010). Professor Bowman also has noted the aptness of the analogy. See Frank O. Bowman III, Debacle: How the Supreme Court Has Mangled American Sentencing Law and How It Might Yet Be Mended, 77 U. CHI. L. REV. (forthcoming 2010) (manuscript at 81), available at http://ssrn.com/abstract=1470516 ("But read in the context of the Blakely line, Ice feels like an excursion into a judicial version of Bizarro World of old Superman comics ....").

2. See Rita v. United States, 551 U.S. 338, 384 (2007) (Souter, J., dissenting) ("Applying the Sixth Amendment to current sentencing law has gotten complicated, and someone coming cold to this case might wonder how we reached this point.").

3. See, e.g., Rachel E. Barkow, The Court of Life and Death: The Two Tracks of Constitutional Sentencing Law and the Case for Uniformity, 107 MICH. L. REV. 1145 (2009) (discussing and criticizing the significant differences between the constitutional law of capital sentencing and the constitutional law of non-capital sentencing).

4. See, e.g., Hamdi v. Rumsfeld, 542 U.S. 507, 533 (2004) (holding that procedural due process requires neutral decision-maker); McCleskey v. Kemp, 481 U.S. 279 (1987) (recognizing the possibility of an equal protection challenge to the motivation of a sentencing decision-maker); Ward $v$. Village of Monroeville, 409 U.S. 57, 61-62 (1972) (holding that the petitioner was entitled to a neutral and detached decision-maker). 
of determining each particular defendant's sentence. ${ }^{5}$

Beginning with its landmark Apprendi decision in 2000, the United States Supreme Court has dramatically repudiated this traditional answer. ${ }^{6}$ In just ten years, the Court has used a series of significant decisions to develop an extensive new constitutional law of sentencing. ${ }^{7}$ Most prominently, the decisions in Blakely and Booker declared that mandatory sentencing guidelines which had bound state and federal judges in the determination of sentences were unconstitutional. ${ }^{8}$ By invalidating these provisions, the Court has used its new constitutional law of sentencing to restore the power of sentencing judges to exercise their discretion in imposing sentences; in doing so, the Court has privileged the objective of an individualized punishment for each particular offender over the objective of systemic uniformity in maintaining consistent treatment of similar facts in similar cases. ${ }^{9}$

In the abstract, there is nothing objectionable about the concept of having a constitutional law of sentencing. Especially with contemporary "sentencing reform" measures becoming more frequent and more pervasive since the mid$1980 \mathrm{~s},{ }^{10}$ the imposition of some constitutional constraints on

5. The Court had rejected the only procedural due process challenges to sentencing process it had heard. See McMillan v. Pennsylvania, 477 U.S. 79, 84-93 (1986) (upholding the imposition of the statutory mandatory minimum sentence based on judge's finding of fact by preponderance of evidence that defendant visibly possessed a firearm during an aggravated assault offense); Williams v. New York, 337 U.S. 241, 244-51 (1949) (upholding a death sentence based on judge's use of hearsay evidence of uncharged additional crimes and bad moral character to find that defendant could not be rehabilitated).

6. In order of decision, the Court's early cases are: Almendarez-Torres v. United States, 523 U.S. 224 (1998); Monge v. California, 524 U.S. 721 (1998); Jones v. United States, 526 U.S. 227 (1999); Apprendi v. New Jersey, 530 U.S. 466 (2000); United States v. Cotton, 535 U.S. 625 (2002); Harris v. United States, 536 U.S. 545 (2002); Ring, 536 U.S. 584.

7. In order of decision, the Court's subsequent, cases are: Blakely v. Washington, 542 U.S. 296 (2004); United States v. Booker, 543 U.S. 220 (2005); Cunningham v. California, 549 U.S. 270 (2007); Rita v. United States, 551 U.S. 338 (2007); Gall v. United States, 552 U.S. 38 (2007); Kimbrough v. United States, 552 U.S. 85 (2007); Oregon v. Ice, 129 S. Ct. 711 (2009); Spears v. United States, 129 S. Ct. 840 (2009) (per curiam).

8. See Booker, 543 U.S. at 243-44; Blakely, 542 U.S. at 304.

9. See Benjamin J. Priester, The Canine Metaphor and the Future of Sentencing Reform: Dogs, Tails, and the Constitutional Law of Wagging, 60 S.M.U. L. REv. 209, 259-70 (2007) [hereinafter Priester, Canine Metaphor].

10. See Benjamin J. Priester, Structuring Sentencing: Apprendi, the Offense of Conviction, and the Limited Role of Constitutional Law, 79 IND. L.J. 863, 
sentencing-related laws likely was inevitable. After all, even the justices who dissented from the Court's early Apprendi doctrine decisions conceded the need for at least some minimal constitutional limits on legislative power. ${ }^{11}$

In reality, however, the constitutional law of sentencing the Court actually developed is subject to several serious objections. For one, the Court has grounded its analysis in the defendant's Sixth Amendment right to a jury trial, yet the doctrines promulgated in its decisions have nothing to do with protecting jury power. ${ }^{12}$ For another, the Court's doctrine produces bizarre outcomes when applied, having the effect of treating functionally identical sentencing findings differently based on formalistic criteria unrelated to the substantive merits of the sentence. ${ }^{13}$ And the Court has unjustifiably constitutionalized the primacy of individualized punishment over systemic uniformity in sentencing particular defendants, when in fact the balance between those competing values at sentencing should have remained a nonconstitutional policy choice entrusted to state and federal legislatures, not to the preferences of judges. ${ }^{14}$

The Court could have been forgiven for initial missteps in its incipient doctrine if it had corrected course in later decisions. But the Court has not done so. Instead, its most recent decisions have only made the analytical flaws worse, and have only compounded the problems its doctrines create.

Today, the Court's new constitutional law of sentencing is all but unrecognizable when compared to its origin in Apprendi. The absurd formalisms embedded in the doctrine have been exacerbated. The doctrine now provides an incentive for sentencing judges to reason more arbitrarily and less transparently when determining punishment. And the doctrine has completely lost touch with any basis in jury trial rights, instead focusing entirely on protecting judicial power.

868-71 (2004) [hereinafter Priester, Structuring Sentencing]; see also infra note 17 (citing sources discussing origins and development of sentencing reform).

11. See infra notes 146-149 and accompanying text.

12. See Priester, Canine Metaphor, supra note 9, at 224-26; see also Priester, Structuring Sentencing, supra note 10, at 891-902 (defending a limited version of the Apprendi doctrine in part based on protecting jury's role in criminal procedure).

13. See Priester, supra note 9, at 221-24; see also infra Part III.A.2.

14. See Priester, supra note 9, at 266-69; see also infra Parts III.A.3, III.B.3-C. 
In fact, the Court has become almost brazen in its emphasis on judicial power, claiming for sentencing judges the authority to engage in "policy nullification" by declining to follow legislatively-adopted sentencing policies in favor of the judges' own policy preferences. Worse, this authority is not constrained to discarding the implicit spirit of the law so long as the judge follows its literal letter, but seemingly extends to a constitutionally mandated authority to ignore express declarations of sentencing policy enacted in statutes.

The time has come for the Court to recognize these serious problems with the new constitutional law of sentencing, and to correct course by bringing the doctrine back to its foundational principles. To do so the Court will have to overturn several of its own recent precedents and roll back the scope of constitutional law in this area. It may be true that legislatures have enacted a wide range of unwise, if not downright stupid, sentencing policies over the last quarter century. But not every poor policy choice is unconstitutional, and the solution to bad legislative judgment should not be bad constitutional law.

\section{BACKGROUND: THE NEW CONSTITUTIONAL LAW OF SENTENCING}

Since its inception, the Court's Apprendi doctrine has generated no shortage of analysis and commentary. Literally hundreds of law review articles, student notes, and other publications have addressed the decisions and their holdings, dicta, rationales, aftermath, and implications. ${ }^{15}$ Simply

15. This extensive commentary has continued in the aftermath of the Court's post-Booker decisions. See, e.g., Lynn Adelman \& Jon Deitrich, Improving the Guidelines Through Critical Evaluation: An Important New Role for District Courts, 57 DRAKE L. REV. 575 (2009); W. David Ball, Heinous, Atrocious, and Cruel: Apprendi, Indeterminate Sentencing, and the Meaning of Punishment, 109 CoLUM. L. REV. 893 (2009); Barkow, supra note 3; Douglas A. Berman, Rita, Reasoned Sentencing, and Resistance to Change, 85 DENV. U. L. REv. 7 (2007); Stephanos Bibas \& Susan Klein, The Sixth Amendment and Criminal Sentencing, 30 CARDOzo L. REv. 775 (2008); Stephanos Bibas et al., Policing Politics at Sentencing, 103 Nw. U. L. REv. 1371 (2009); Bowman, supra note 1; Mark Chenoweth, Using Its Sixth Sense: The Roberts Court Revamps the Rights of the Accused, 2009 CATO SUP. CT. REv. 223, 225-246; D. Michael Fisher, Striking a Balance: The Need to Temper Judicial Discretion Against a Background of Legislative Interest in Federal Sentencing, 46 DUQ. L. REv. 65 (2007); Bradley R. Hall, Mandatory Sentencing Guidelines By Any Other Name: When "Indeterminate Structured Sentencing" Violates Blakely v. Washington, 57 
explaining thoroughly each of the Court's decisions, one by one, could consume a law review article just by itself. ${ }^{16}$ Moreover, the Apprendi doctrine is situated within a much broader political and intellectual debate-among not only scholars, but also practitioners, judges, legislators, and other policy-makers-over what commonly is referred to as "sentencing reform," a subject with an even larger existing body of commentary. ${ }^{17}$ Each new contribution to the debate over the Apprendi doctrine, then, builds upon much that has come before.

On the other hand, the Court's new constitutional law of sentencing is sufficiently complicated that a basic synopsis of the doctrine is necessary to lay the groundwork for any analytical discussion of it. The sections that follow describe the scope of the Court's current version of the Apprendi doctrine, as well as the seeds of potential further development contained in the Court's decisions.

Before beginning, however, it is necessary to clarify two important points of terminology. First, I use two labels to refer to different types of statutes: offense-defining and sentencing-regulating. ${ }^{18}$ An offense-defining statute is one

Drake L. REv. 643 (2009); Carissa Byrne Hessick \& F. Andrew Hessick, Appellate Review of Sentencing Decisions, 60 ALA. L. REv. 1 (2008); Susan R. Klein \& Sandra Guerra Thompson, DOJ's Attack on Federal Judicial "Leniency," the Supreme Court's Response, and the Future of Criminal Sentencing, 44 TULSA L. REV. 519 (2009); Susan F. Mandiberg, Why Sentencing by a Judge Satisfies the Right to Jury Trial: A Comparative Law Look at Blakely and Booker, 40 MCGEORGE L. REV. 107 (2009); Michael M. O'Hear, Explaining Sentences, 36 FLA. ST. U. L. REV. 459 (2009); Mary Kreiner Ramirez, Into the Twilight Zone: Informing Judicial Discretion in Federal Sentencing, 57 DRAKE L. REV. 591 (2009); Kate Stith, The Arc of the Pendulum: Judges, Prosecutors, and the Exercise of Discretion, 117 YALE L.J. 1420 (2008). Numerous articles followed the Court's earlier decisions in Booker, Blakely, and Apprendi. See Priester, Canine Metaphor, supra note 9, at 217 n.33, 216 n.29, 215 n. 18 (citing sources); Priester, Structuring Sentencing, supra note 10, at 864 nn.2 \& 7, 871 n.45 (citing sources).

16. See, e.g., Bowman, supra note 1, at 11-84.

17. See, e.g., Lynn Adelman \& Jon Deitrich, Marvin Frankel's Mistakes and the Need to Rethink Federal Sentencing, 13 BERKELEY J. CRIM. L. 239 (2008) (discussing the origins of sentencing reform policies and criticizing their trajectory in federal sentencing); Douglas A. Berman \& Stephanos Bibas, Making Sentencing Sensible, 4 OHIO ST. J. CRIM. L. 37 (2006) (discussing the impact of Apprendi and Blakely on sentencing reform measures nationwide); see also, e.g., Bowman, supra note 1, at 3-11; Fisher, supra note 15, at 67-74; Klein \& Thompson, supra note 15, at 521-35; Stith, supra note 15, at 1427-43.

18. See Priester, Structuring Sentencing, supra note 10, at 899, 908; Benjamin J. Priester, Constitutional Formalism and the Meaning of Apprendi v. 
that, on its face, expressly undertakes to define the elements of a criminal offense. Such a statute usually also delineates the available punishment for a violation of that offense, either within the statute itself ("up to twenty years") or by reference ("a class B felony"). Sometimes the statute may define several grades of the offense within the same section, as with the three-tiered principal federal narcotics offense, $\S 841 .{ }^{19} \mathrm{~A}$ sentencing-regulating provision, by contrast, is one that expressly does not define the elements of a separate offense, but rather explicitly addresses only the determination of punishment for a violation. So-called "sentencing guidelines" are one form of a sentencing-regulating provision, but there are others as well, including mandatory minimums and recidivist or "three strikes" enhancements. Some of these regulations of sentencing authority are contained in statutes enacted by legislatures, like the Washington state sentencing guidelines in Blakely; others, like the Federal Sentencing Guidelines prior to Booker, are promulgated by other methods but are nonetheless mandatory provisions of law binding upon sentencing judges. ${ }^{20}$ Much of the Apprendi doctrine's development has involved the Court imposing constitutional constraints on the legislature's use of sentencing-regulating provisions to restrict the authority of sentencing judges.

Second, I use two additional labels to refer to different types of factfinding and the procedures used to make them: verdict facts and extraverdict facts. Verdict facts are the facts established beyond a reasonable doubt by the guilty verdict resulting from a conviction at a trial, or a defendant's admission in a guilty plea. Because the Court has justified its Apprendi doctrine under the Sixth Amendment jury trial right, its rhetoric often refers to the necessity of jury factfinding of certain facts, even in cases where the defendant actually pled guilty or was convicted in a bench trial. ${ }^{21}$ To

New Jersey, 38 AM. CRTM. L. REV. 281, 284-85, 301-08 (2001) [hereinafter Priester, Constitutional Formalism].

19. See 21 U.S.C. § 841(a)-(b) (2006).

20. The Federal Sentencing Guidelines are promulgated by the Sentencing Commission, an agency created by Congress with delegated power to devise the Guidelines. See generally Mistretta v. United States, 488 U.S. 361 (1989) (upholding the constitutionality of the Sentencing Commission against a separation of powers challenge).

21. For example, Apprendi pled guilty, see Apprendi v. New Jersey, 530 U.S. $466,469-70$ (2000), while Harris was convicted in a bench trial, see Harris v. 
avoid confusion and maintain consistency of usage, I prefer the label "verdict facts" to encompass the factual elements of the offense of conviction. By contrast, extraverdict facts are those additional facts considered at sentencing that were not established as verdict facts. These extraverdict facts might be found by the sentencing judge in the exercise of sentencing discretion, or pursuant to the instructions of a sentencingregulating provision. Typically, sentencing-regulating provisions, like sentencing guidelines, call for factfinding by a preponderance of the evidence. ${ }^{22}$ Thus, extraverdict facts frequently involve a different factfinder and a different burden of proof than verdict facts. Another significant component of the Court's development of the Apprendi doctrine has involved imposing constitutional constraints on the use of extraverdict factfinding when determining a defendant's sentence.

\section{A. Defining Apprendi Violations}

The basic principle of the Apprendi doctrine is straightforward: the Apprendi doctrine renders unconstitutional the use of extraverdict factfinding to justify imposing a longer sentence than would have been permissible under the law based solely on the verdict facts. ${ }^{23}$ Thus, the doctrine does not abolish all judicial factfinding at sentencing, nor does it require that every fact used to increase a sentence be a verdict fact. Instead, the doctrine is concerned only with the relationship between the verdict facts and the defendant's maximum punishment.

What is less straightforward-and more controversial-is the Court's determination of what qualifies as the offender's

United States, 536 U.S. 545, 551 (2002).

22. See, e.g., United States v. Booker, 543 U.S. 220, 235 (2005); Blakely v. Washington, 542 U.S. 296, 300 (2004); Harris, 536 U.S. at 551.

23. The Apprendi doctrine currently has one exception: when the extraverdict fact used to increase the sentence is recidivism. See, e.g., Apprendi, 530 U.S. at 490 ("Other than the fact of a prior conviction, any fact that increases the penalty for a crime beyond the prescribed statutory maximum must be submitted to a jury, and proved beyond a reasonable doubt.") (emphasis added). Although a majority of the justices on the Court no longer support retaining the recidivism exception, see Shepard v. United States, 544 U.S. 13, 27 (2005) (Thomas, J., concurring), the Court has yet to formally reconsider it. For further analysis of the recidivism exception, see, e.g., Priester, Canine Metaphor, supra note 9, at 213 \& n.8 (citing sources); Priester, Structuring Sentencing, supra note 10 , at $876-78$. 
maximum punishment "under the law" for purposes of the Apprendi doctrine. Over the course of its decisions, the Court has expanded the kinds of factfinding that fall within the doctrine's proscription. This expansion has progressed through two steps, and may be poised to take a third.

\section{Maximum Sentences Set By Offense-Defining Statutes (Apprendi)}

The Apprendi doctrine arose in cases involving punishment levels contained in the statutes defining the offenses for which the defendants had been convicted. Using the doctrine, the Court held that those punishment levels had constitutional significance, such that the maximum sentence imposed on the defendant could not exceed the punishment level that corresponded to the verdict facts. Consequently, higher sentences imposed based on extraverdict facts were unconstitutional.

The facts of the cases illustrate the operation of this doctrine's first iteration. In Apprendi, the state firearms offense carried a base penalty range of five-to-ten years and an extended range of ten-to-twenty years, if various additional facts were proven. ${ }^{24}$ Apprendi pled guilty to the offense, but did not admit any of those additional facts as part of his plea; nevertheless, the sentencing judge found by a preponderance of the evidence that his offense was a hate crime and sentenced him to twelve years. ${ }^{25}$ The Court reversed, holding that the sentence was unconstitutional because an extraverdict fact was used to impose a sentence greater than the ten year maximum that corresponded to the verdict facts. ${ }^{26}$ Similarly, the federal crime in Jones had three sentencing tiers: up to fifteen years' imprisonment for the carjacking offense, up to twenty-five years' imprisonment if serious bodily injury resulted, and up to life imprisonment if a death resulted. ${ }^{27}$ At trial, the jury was not instructed to make a finding of serious bodily injury; instead, that fact was found by a preponderance of the evidence by the sentencing judge, who sentenced Jones to twenty-five years. ${ }^{28}$ The Court

24. See Apprendi, 530 U.S. at $468-69$.

25. See id. at 469-71.

26. See id. at 491-92.

27. See Jones v. United States, 526 U.S. 227, 230-32 (1999).

28. See id. at 231. 
reversed, ruling that a sentence longer than fifteen years was not authorized by the statute unless the fact of serious bodily injury was established as a verdict fact. ${ }^{29}$ Finally, the Court held in Ring that the statutory aggravating factors necessary to impose a death sentence, rather than life imprisonment, for capital murder must be established as verdict facts. ${ }^{30}$

The application of the Apprendi doctrine to maximum sentences in offense-defining statutes is easily defensible. The Court has justified it under the Sixth Amendment's Jury Trial Clause, emphasizing that one important traditional function of the jury was to interpose the citizenry between the defendant and the imposition of criminal sanctions. ${ }^{31}$ To impose a sentence greater than the one provided in the offense for which the jury convicted, therefore, contravenes the jury's constitutional power to establish verdict facts. It is the constitutional equivalent of convicting the defendant of an aggravated offense without following the constitutionally mandated process. ${ }^{32}$ Similarly, in Structuring Sentencing I defended this component of the doctrine using a similar but broader rationale: the constitutional structure of criminal procedure. ${ }^{33}$

29. See id. at 251-52. Because Jones involved a federal criminal statute, the Court's holding in that case was limited to addressing the authorized punishment as a question of statutory interpretation-but the Court's analysis was strongly influenced by the interpretive canon of constitutional avoidance (which instructs the court to construe statutes in a manner that saves their constitutionality if it is possible to do so), based on the constitutional principle it formally adopted the following year in its holding in Apprendi. See id. at 24344,243 n.6, 252.

30. See Ring v. Arizona, 536 U.S. 584, 593-93, 600-05 (2002).

31. See, e.g., United States v. Booker, 543 U.S. 220, 235-37 (2005); Blakely v. Washington, 542 U.S. 296, 305-14 (2004); Apprendi v. New Jersey, 530 U.S. $466,476-90(2000)$; id. at 498-99 (Scalia, J., concurring); id. at 500-23 (Thomas, J., concurring).

32. See, e.g., Harris v. United States, 536 U.S. 545, 557 (2002) (“Apprendi said that any fact extending the defendant's sentence beyond the maximum authorized by the jury's verdict would have been considered an element of an aggravated crime . . . by those who framed the Bill of Rights."); Monge v. California, 524 U.S. 721, 741 (1998) (Scalia, J., dissenting) ("I believe that for federal constitutional purposes those extra four years are attributable to conviction of a new crime.").

33. See Priester, Structuring Sentencing, supra note 10 (defending the application of the Apprendi doctrine to maximum sentences in offense-defining statutes under a constitutional structure of criminal procedure rationale). 


\section{Maximum Sentences Set By Sentencing-Regulating Provisions (Blakely)}

Once the Apprendi doctrine was adopted, defendants' constitutional challenges to their sentences naturally progressed to the next logical step: sentencing guidelines and similar provisions expressly relying on extraverdict facts to determine punishment. Unlike the statutes in the earlier cases, these provisions expressly disclaim any role in defining substantive offenses or expanding criminal liability. Rather, they regulate and constrain the decision-making of the judge who imposes sentence after a conviction upon verdict facts has been obtained. Nevertheless, the Court held that such mandatory sentencing provisions also have constitutional significance, and ruled unconstitutional the increased sentences imposed by extraverdict facts.

This second iteration of the Apprendi rule invalidated several different forms of sentencing-regulating provisions. In Blakely, the defendant was convicted of kidnapping, an offense carrying a maximum punishment of ten years' imprisonment. ${ }^{34}$ Under the legislatively promulgated statutory state sentencing guidelines in Washington, the punishment range was forty-nine to fifty-three months based only on the verdict facts. ${ }^{35}$ At sentencing, however, the judge found by a preponderance of the evidence that Blakely committed his crime with deliberate cruelty, and accordingly imposed a sentence of ninety months. ${ }^{36}$ The Court held the increased sentence unconstitutional because it exceeded the punishment authorized under the sentencing-regulating statutes for the verdict facts. ${ }^{37}$

Similarly, the defendant in Booker was convicted of narcotics distribution, a federal offense carrying a statutory punishment range of ten years to life. ${ }^{38}$ Under the Federal Sentencing Guidelines, promulgated by the United States Sentencing Commission pursuant to power delegated to the agency by Congress, the punishment range based only on the verdict facts was 210-262 months. ${ }^{39}$ Based on additional,

34. See Blakely, 542 U.S. at 298-300.

35. See id.

36. See id.

37. See id. at 303-05.

38. See United States v. Booker, 543 U.S. 220, 227 (2005).

39. See id. 
extraverdict findings of drug quantity and obstruction of justice, the sentencing judge imposed 360 months. ${ }^{40}$ The Court likewise invalidated this sentence, applying Blakely. ${ }^{41}$

Finally, the defendant in Cunningham was convicted of a child sex abuse offense with three specific available sentences: six, twelve, or sixteen years' imprisonment. ${ }^{42}$ Applying California's Determinate Sentencing Law, the sentencing judge found several aggravating circumstances were present and imposed the upper term sentence. ${ }^{43}$ The Court reversed, concluding that, as in Blakely and Booker, extraverdict factfinding had been used to impose a sentence longer than the maximum available based on the verdict facts. ${ }^{44}$

In 2009, however, the Court recognized a significant exception to the Blakely expansion of the Apprendi doctrine: the imposition of consecutive sentences for multiple convictions in the same trial. In Ice, the defendant was convicted on six counts, including one burglary charge and two charges of child sexual assault for a pair of incidents about eight months apart. ${ }^{45}$ Running all six counts concurrently, Ice's sentence would have been ninety months. ${ }^{46}$ Instead, the sentencing judge made extraverdict findings that resulted in running four of the six charges consecutively, and imposed a sentence of 340 months. ${ }^{47}$ The five-justice majority in Ice affirmed the sentence, arguing that the decision whether to impose consecutive or concurrent sentences had always rested historically with the sentencing judge, such that it could not be considered part of the jury's role protected

40. See id. The facts were similar in the consolidated, companion case of United States v. Fanfan: the statutory range was five to forty years, the verdictfacts Guidelines range was sixty-three to seventy-eight months, and the judge imposed 188 months based on extraverdict factfinding of drug quantity and defendant's leadership role in the crime. See id. at 228.

41. See id. at 231-35.

42. See Cunningham v. California, 549 U.S. 270, 274-76 (2007).

43. See id. at $275-76,276$ n.2.

44. See id. at $288-93$.

45. See Oregon v. Ice, 129 S. Ct. 711,715 (2009).

46. See id. at 716 n.5.

47. See id. at 715-16. The judge found that the two burglaries should be sentenced consecutively from each other, and that two of the sexual assault convictions should also be sentenced consecutively from each other and from the burglary counts, but ran the remaining two sexual assault convictions concurrently. See id. 
by the Apprendi doctrine. ${ }^{48}$ The four-justice dissent rejected that analysis, insisting that because the state sentencing statutes mandated concurrent sentences unless additional facts were established, the imposition of consecutive sentences based on extraverdict facts was indistinguishable from the sentence increases invalidated by the Apprendi doctrine. ${ }^{49}$ Thus, although the Blakely expansion limits the use of extraverdict facts to increase the sentence for a single offense, it does not apply to determinations about how to combine punishment when sentencing for multiple offenses.

The Blakely expansion of the doctrine diverges from the core rationale underlying Apprendi. In these cases, there can be no doubt that the sentence imposed fell within the punishment scope of the offense defined by the verdict facts; there is no argument that the sentencing judges acted ultra vires by convicting the defendant of an aggravated offense based on extraverdict facts rather than verdict facts. The Court implicitly concedes as much, shifting its analysis to whether the otherwise-permissible sentence was nevertheless necessarily contingent upon extraverdict facts. According to the Court, if the longer sentence would constitute reversible error under the sentencing-regulating provisions but for the extraverdict facts, then the verdict facts alone did not authorize that sentence. ${ }^{50}$ Thus, under Blakely, the verdict facts delimit not only the offense of conviction, but also the operation of mandatory sentencing provisions that bind the power of sentencing judges. In Structuring Sentencing and The Canine Metaphor, I explained why the Blakely expansion of Apprendi was unjustified. ${ }^{51}$

\section{Maximum Sentences Set By Appellate Review As Applied (Coming Soon?)}

In several recent cases, Justice Scalia has argued that

48. See id. at 716-18.

49. See id. at $720-23$ (Scalia, J., dissenting).

50. See, e.g., Cunningham v. California, 549 U.S. 270, 274-75, 288-89, 29193 (2007) (explaining that, under California's Determinate Sentencing Law, a sentencing judge lacks power to impose an upper term sentence absent a finding of aggravated circumstances); United States v. Booker, 543 U.S. 220, 231-35 (2005); Blakely v. Washington, 542 U.S. 296, 301-05 (2004).

51. See Priester, Structuring Sentencing, supra note 10, at 896-907; Priester, Canine Metaphor, supra note 9, at 221-26, 260-66 (explaining the lack of justification for the expansion of the Apprendi doctrine through Blakely). 
the Apprendi doctrine necessitates an additional expansion: giving constitutional significance to maximum sentences created not by offense-defining statutes or sentencingregulating provisions on their faces, but rather by the asapplied operation of appellate review of sentences imposed by trial courts. ${ }^{52} \mathrm{He}$ argues that to the extent the length of the sentence could not be upheld on appellate review without the presence of certain facts, those facts also must be established as verdict facts under Apprendi. Because Justice Scalia has long been the leader in shaping the scope of the Apprendi doctrine, his analysis in these cases must be taken seriously. ${ }^{53}$

Justice Scalia presented his argument in cases involving the application of post-Booker reasonableness review of federal sentences, as discussed further below, ${ }^{54}$ but his analysis equally applies to all appellate review of the substantive justification for sentences, including in nonguidelines or discretionary sentencing regimes. His basic position is simple. In any sentencing regime in which the trial court lacks complete discretion to impose any sentence up to the statutory maximum based solely on the verdict facts, then "for every given crime there is some maximum sentence that will be upheld as reasonable based only on the [verdict facts] . . . Every sentence higher than that is legally authorized only by some judge-found fact, [and is] in violation of" the Apprendi doctrine as-applied. ${ }^{55}$

Consider, for example a post-Booker federal robbery conviction that has a baseline sentence of thirty-three to forty-one months, but which, based on three additional Guidelines facts, has an advisory sentence of 235-293

52. See Rita v. United States, 551 U.S. 338, 370-84 (2007) (Scalia, J., concurring); Kimbrough v. United States, 552 U.S. 85, 112-14 (2007) (Scalia, J., concurring); Gall v. United States, 552 U.S. 38, 60 (2007) (Scalia, J., concurring).

53. See Priester, Canine Metaphor, supra note 9, at 233 n.113 (discussing Justice Scalia's leading role in Apprendi doctrine cases). The only merits opinion in the Apprendi line of cases in which Justice Scalia was not on the majority side is the 2009 decision in Oregon v. Ice, 129 S. Ct. 711 (2009). See also infra Part II.C (describing and discussing views of the various justices in Apprendi doctrine cases).

54. See infra Part II.B.

55. Rita, 551 U.S. at 372-73 (Scalia, J., concurring); see also Marlowe v. United States, 129 S. Ct. 450 (2008) (Scalia, J., dissenting from the denial of certiorari). 
months. ${ }^{56}$ Justice Scalia argues it "is evident" that a sentence of 293 months "would surely be reversed as unreasonably excessive" without a finding of those three facts to justify its length. ${ }^{57}$ Consequently, those three facts "are the legally essential predicate for [the] imposition of the 293-month sentence" and the Apprendi doctrine mandates that the findings be made as verdict facts, not extraverdict facts. ${ }^{58} \mathrm{He}$ concludes that "there is a fundamental difference, one underpinning our entire Apprendi jurisprudence, between facts that must be found in order for a sentence to be lawful, and facts that individual judges choose to make relevant to the exercise of their discretion." ${ }^{99}$ For Justice Scalia, it is irrelevant whether the facts must be found because a statute or guideline facially commands it, or because appellate review as-applied commands it-and appellate review commands the facts must be found in any situation where the sentence would not be upheld on appeal without the additional facts to justify its length. ${ }^{60}$

Like the Blakely expansion, Justice Scalia's proposed additional expansion diverges far from the core rationale of the Apprendi doctrine. His as-applied argument, if accepted by the Court, would move constitutional restrictions far deeper into the determination of a defendant's sentence than the Court has already gone. Given Justice Scalia's successful track record in shaping the development of the Apprendi doctrine, that acceptance may very well occur sooner rather than later. ${ }^{61}$ Accordingly, I address several significant

56. See Rita, 551 U.S. at 372.

57. $I d$.

58. $I d$.

59. Id. at 373

60. See id. at $370-74$.

61. In May 2010, the Court avoided this constitutional issue entirely in a sentencing case by reaching its decision on grounds of statutory interpretation. See United States v. O'Brien, 130 S. Ct. 2169, 2173-74, 2180 (2010). The defendants pled guilty to several charges arising from an attempted robbery of an armored car, including one count of violating § 924(c), due to the presence of firearms during the offense. See id. at 2173-74. Under the statute, the defendants faced sentences of five years to life for possessing a gun, seven years to life if the gun was brandished, and thirty years to life if the gun was a machinegun. See $i d$. at 2175-76 (quoting 18 U.S.C. $\S 924(\mathrm{c})(1)(\mathrm{A})(\mathrm{i})$-(ii) \& (B)(i)-(ii) (1998)). The district court held that the nature of the firearm as a machinegun was an element of the offense, and the Government conceded it could not prove that fact beyond a reasonable doubt. See id. at 2173. Accordingly, the district court refused to apply the thirty years minimum 
critiques of Justice Scalia's as-applied position below.

\section{But Not Mandatory Minimum Sentences (Harris-For Now)}

Finally, it is worth emphasizing that the Court has limited the application of the Apprendi doctrine to the facts that determine the defendant's maximum sentence. The Court has followed this course even though the operation of mandatory minimum sentencing provisions has a comparable effect: to compel the imposition of more punishment on the defendant than would otherwise be imposed. It seems possible, therefore, that the Court may reverse course and extend the Apprendi doctrine to prohibit use of extraverdict facts in determining the bottom and top ends of the authorized punishment for each defendant.

The exclusion of mandatory minimum provisions from the Apprendi doctrine is a consequence of the Court's divided opinion in Harris. In that case, the defendant was convicted

sentence; the court of appeals affirmed, relying heavily on a prior Supreme Court decision construing an earlier version of the statute. See id. at 2174 (discussing Castillo v. United States, 530 U.S. 120 (2000)). Because the defendants admitted to brandishing the guns during the offense, the district court sentenced one defendant to seven years and the other to eight and a half years on the $\S 924$ (c) count. See id. at 2174. In their briefs to the Court, the defendants had urged the Court to apply the doctrine of constitutional avoidance, relying on Justice Scalia's argument: because a sentence of thirty years on the $\S 924$ (c) count would not be upheld on appeal (under Booker-Rita reasonableness review, see infra Part II.B.2.) absent the machinegun finding, the statute must be construed as making that finding a verdict fact to avoid a violation of Apprendi-Booker. See Brief for Respondent O'Brien at 37-55, O'Brien, 130 S. Ct. 2169 (No. 08-1569); Brief for Respondent Burgess at 29-43, O'Brien, 130 S. Ct. 2169 (No. 08-1569).

Thus, O'Brien presented an opportunity for the Court to address Justice Scalia's position. The opinion for the Court by Justice Kennedy, however, discussed only issues of statutory interpretation in ruling that the finding of a machinegun must be made as a verdict fact. See O'Brien, $130 \mathrm{~S}$. Ct. at 2165-80. The solo concurring opinions by Justice Stevens and Justice Thomas did address the constitutional implications of $\S 924(c)$, but only by calling for the Court to overrule its prior decisions in McMillan and Harris; neither opinion made reference to Justice Scalia's position or its implications for the facts in O'Brien. See id. at 2181-83 (Stevens, J., concurring); id. at 2183-84 (Thomas, J., concurring). Given the narrow basis of the Court's ruling-and the fact that Justice Scalia himself did not write separately to discuss the application of his constitutional position to the facts of the case--it seems likely that the O'Brien decision does not provide any meaningful signals about how many other justices, if any, might be willing to adopt Justice Scalia's position in a case where it is squarely presented. See infra Part II.C. (discussing the diverging views of the justices on numerous Apprendi-Blakely issues). 
at trial of one count of the $\S 924$ (c) federal firearms offense, which authorizes a punishment of five years to life for using, carrying, or possessing a firearm during a narcotics offense, as well as seven years to life if the firearm is brandished, and ten years to life if it is discharged. ${ }^{62}$ The verdict facts established that Harris carried a firearm during the narcotics offense, and at sentencing, the judge made an additional finding that Harris had brandished the weapon and imposed the seven-year mandatory minimum. ${ }^{63}$ The Court affirmed the sentence, but no rationale gained a majority. A fourjustice plurality argued that the Apprendi doctrine should apply only to the top end of the authorized punishment, and therefore the mandatory increase in the minimum sentence was permissible. ${ }^{64} \mathrm{~A}$ four-justice dissent insisted that the underlying principle of the Apprendi doctrine reached both the top and bottom ends, making the mandatory minimum sentence unconstitutional because it was imposed based on an extraverdict fact, rather than a verdict fact. ${ }^{65}$ Justice Breyer's decisive concurring opinion, speaking only for himself, agreed with the dissent on the logic of its principle but joined the majority on the result. ${ }^{66}$ Consequently, while the doctrinal result in Harris remains good law, its weight as precedent is weak. To date, however, the Court has not granted certiorari in a case that squarely presents the issue of revisiting Harris. ${ }^{67}$

62. See Harris v. United States, 536 U.S. 545, 550-51, 554 (2002) (discussing 18 U.S.C. $\$ 924(c)(1)(A)(2000)$ ).

63. See id. at 550-52. In Harris, the verdict facts were established by conviction at a bench trial. See id. at 551 .

64. See id. at 556-68 (Kennedy, J., plurality opinion).

65. See id. at 572-80 (Thomas, J., dissenting).

66. See id. at 569-72 (Breyer, J., concurring). Justice Breyer agreed that not applying the Apprendi doctrine to minimum sentences was illogical, but refused to join the dissenting opinion in forming a majority for that doctrinal outcome because he believed Apprendi was wrongly decided and accordingly should be applied narrowly. See id.

67. The opinion for the Court in O'Brien did not broach the issue of the continued validity of Harris. See supra note 61 (discussing the facts and opinions in $O^{\prime} B r i e n$ ). This is not surprising, as the prospect of overruling Harris was not briefed and argued as a question presented in O'Brien. See Transcript of Oral Argument at 19-21, United States v. O'Brien, 130 S. Ct. 2169 (2010) (No. 08-1569). Nevertheless, during the oral argument in $O^{\prime} B r i e n$, Justice Breyer suggested that he might be willing to reconsider his dispositive vote in Harris and vote to overrule that decision. Id. at 19 ("But in Harris, I said that I thought Apprendi does cover mandatory minimums, but I don't accept Apprendi. Well, at some point I guess I have to accept Apprendi, because it's 
The future of the Harris limitation on the Apprendi doctrine depends on the future scope of the doctrine itself. In Structuring Sentencing, I defended the Apprendi-Harris rule as fully consistent with the constitutional structure of criminal procedure. ${ }^{68}$ The Court, however, has extended the Apprendi doctrine to also include the Blakely expansion. If this position remains controlling, it is difficult to see why Harris should not be overruled ${ }^{69}$-especially if the Court further extends Blakely to reach Justice Scalia's as-applied position.

the law and has been for some time."); see also O'Brien, $130 \mathrm{~S}$. Ct. at $2183 \mathrm{n.6}$ (Stevens, J., concurring) (quoting Justice Breyer's comments during oral argument). Moreover, the facts of O'Brien more directly implicated Justice Scalia's position on as-applied Blakely challenges (because the thirty years sentence would exceed the maximum otherwise-permissible, verdict-factsauthorized sentence on the gun charge), rather than implicating a true increase in a minimum sentence beneath a verdict-facts-authorized maximum. To squarely confront Harris, it seems likely the Court would need to review a case raising the latter factual scenario.

In O'Brien, only the concurring opinions of Justice Stevens and Justice Thomas discussed the continued validity of Harris, and both justices explicitly called for overruling it. See O'Brien, $130 \mathrm{~S}$. Ct. at 2181-83 (Stevens, J., concurring); id. at 2183-84 (Thomas, J., concurring). Interestingly, Justice Ginsburg did not join either opinion, despite having joined the original dissent in Harris. Similarly of interest, the Court had decided a case in the previous Term involving a true mandatory-minimum increase under this very statute, yet did not reconsider the Harris holding in its decision there. See Dean v. United States, $129 \mathrm{~S}$. Ct. 1849 (2009). Thus, it is difficult to predict when the Court might revisit Harris in a future case.

68. See Priester, Structuring Sentencing, supra note 10, at 902-09 (defending the Apprendi-Harris rule as consistent with the constitutional structure of criminal procedure); see also Priester, Canine Metaphor, supra note 9 , at 230-31. Justice Alito appears to agree that once the verdict facts determine the maximum available punishment, the use of extraverdict facts to increase the minimum punishment is constitutionally permissible. See Gall v. United States, 551 U.S. 38, 64 (2007) (Alito, J., dissenting)

It would be a coherent principle to hold that any fact that increases a defendant's sentence beyond the minimum required by the jury's verdict of guilty must be found by a jury. Such a holding, however, would clash with accepted sentencing practice at the time of the Id. adoption of the Sixth Amendment.

69. See Priester, Canine Metaphor, supra note 9, at 231-34; see also id. at 233-34 (discussing "the Scalia conundrum," that is, Justice Scalia's divergence in Harris from the other four justices in the Apprendi majority); Bowman, supra note 1 , at 27, 36-37 (discussing the persistence of Justice Scalia's Harris position). 


\section{B. Avoiding Apprendi Violations and Booker-Rita Reasonableness Review}

Most of the decisions developing and applying the Apprendi doctrine resulted in the reversal of the individual defendant's sentence as unconstitutional. More importantly for systemic purposes, the decisions also necessitated changes in drafting or implementing sentencing laws to avoid continued reversals of sentences in future cases.

\section{Responding to Apprendi and Blakely}

Following Apprendi's ruling regarding offense-defining statutes, the natural response was simply to prove the relevant facts as verdict facts. That is, just as Apprendi had characterized them, the facts would be established as elements of an aggravated offense. For example, in a carjacking case like Jones, the fact of serious bodily injury would be submitted to the jury for proof beyond a reasonable doubt, or admitted by the defendant in a guilty plea colloquy, to authorize the longer, twenty-five year penalty. ${ }^{70}$ Similarly, the requisite quantities of narcotics in the three-tiered principal federal narcotics offense, $\S 841$, also became verdict facts when prosecutors sought punishments in the higher tiers. ${ }^{71}$ Indictments now routinely allege facts triggering statutory offense tiers or enhanced statutory punishments. ${ }^{72}$

A more complicated question, however, was how to respond to Blakely's ruling expanding the Apprendi doctrine to reach what are indisputably sentencing-regulating provisions. One option, just as after Apprendi, was to ensure proof of all implicated facts as verdict facts-colloquially referred to as "Blakely-izing" state sentencing guidelines. ${ }^{73}$ That is, facts that previously had been determined by the judge at sentencing now would be required to be submitted to the jury or admitted in a guilty plea; this sustained the

70. See, e.g., United States v. Gonzalez-Mercado, 402 F.3d 294, 296 (1st Cir. 2005) ("[T] he indictment further charged that the carjackings had resulted in serious bodily injury in violation of 18 U.S.C. $\$ 2119(2)$.").

71. See, e.g., United States v. Morris, 524 F.3d 549, 555 n.9 (4th Cir. 2008) (" $[T]$ he threshold drug quantities in $\$ 841$ (b) constitute elements of aggravated drug trafficking offenses. ...”).

72. See, e.g., United States v. O'Brien, 542 F.3d 921, 922-23 (1st Cir. 2008); Gonzalez-Mercado, 402 F.3d at 296.

73. See Priester, Canine Metaphor, supra note 9, at 247-49; see also United States v. Booker, 543 U.S. 220, 246 (2005). 
constitutionality of the lengthened sentences imposed by bringing the factfinding procedures used to establish those facts into compliance with Blakely. ${ }^{74}$ After Blakely, most of the states with mandatory guidelines systems chose to adopt this solution for their sentencing regimes. ${ }^{75}$ The other option was the converse: to eliminate the mandatory nature of the sentencing-regulating provisions so that the lengthened sentence was no longer contingent on extraverdict facts for its legal authorization. ${ }^{76}$ If any sentence, short or long, within the offense-defined maximum punishment actually is legally authorized by the verdict facts alone, then the judge's discretionary consideration of extraverdict facts in selecting a particular punishment, long or short, does not implicate the proscription of Blakely. ${ }^{77}$ Several states with previously mandatory guidelines systems adopted this solution. ${ }^{78}$

In Booker, the Court addressed the question of how to respond to the post-Blakely unconstitutionality of sentences imposed pursuant to the mandatory Federal Sentencing Guidelines. The issue was one of statutory interpretation and congressional intent: given that the operation of the Federal Sentencing Guidelines was unconstitutional under Blakely to the extent it authorized increased maximum punishments using extraverdict facts, ${ }^{79}$ would Congress have wanted (a) the Guidelines to continue to be enforced as binding, but using factfinding by verdict facts, or (b) that the Guidelines instead be transformed into non-binding, advisory sentencing provisions continuing to use extraverdict facts? ${ }^{80}$ With a different alignment of justices than its merits opinion, the Booker Court adopted the latter solution in its remedial opinion. ${ }^{81}$ The remedial dissenters argued that Congress had been concerned primarily with constraining the sentencing power of federal judges, and therefore would have wanted the

74. See Priester, Canine Metaphor, supra note 9, at 248-49.

75. See id. at 248-49 n.180; see also Cunningham v. California, 549 U.S. 270, 294 \& n.17 (2007); Bibas \& Klein, supra note 15, at 785-88, 797-805.

76. See Priester, Canine Metaphor, supra note 9, at 248; see also Booker, 543 U.S. at $233,246$.

77. See, e.g., Booker, 543 U.S. at 234; see also Rita v. United States, 551 U.S. 338 , 369-70 (2007) (Scalia, J., concurring).

78. See Priester, supra note 9 , at 248-49 n.179; see also Cunningham, 549 U.S. at 294 \& n.18; Bibas \& Klein, supra note 15, at 785-88, 797-805.

79. See United States v. Booker, 543 U.S. 220, 230-37 (2005).

80. See id. at 243-49.

81. See infra notes 153-154 and accompanying text. 
Guidelines to retain their binding effect, even if that meant proving many Guidelines facts as verdict facts rather than the extraverdict facts originally contemplated..$^{82}$ By contrast, the remedial majority concluded that Congress primarily valued the extraverdict factfinding and real-offense sentencing system created by the Guidelines, and therefore would have preferred that they have non-binding, advisory effect. ${ }^{83}$

Accordingly, the Booker remedial majority, as a matter of statutory interpretation, severed from the operation of the Guidelines the statutory sections which made the Guidelines mandatory for the sentences imposed by district court judges. ${ }^{84}$ It also severed the statutory section that subjected Guidelines sentences to de novo appellate review. ${ }^{85}$ In their place, the remedial majority held that the Guidelines were

82. See Booker, 543 U.S. at 272-303 (Stevens, J., dissenting); id. at 303-05 (Scalia, J., dissenting); id. at 323-25 (Thomas, J., dissenting); see also Priester, Canine Metaphor, supra note 9, at 265-66 \& nn.232-41.

83. See Booker, 543 U.S. at 246-68 (Breyer, J., majority opinion); see also Priester, Canine Metaphor, supra note 9, at 264-65 \& nn.224-31.

84. See Booker, 543 U.S. at 258-60.

85. See id. at 260-65. Both before and after Booker, a district court's interpretation and application of the Guidelines is a question of law reviewed de novo. See, e.g., United States v. Bates, 584 F.3d 1105, 1108 (8th Cir. 2009); United States v. Ashley, 342 F.3d 850, 852 (8th Cir. 2003); see also Gall v. United States, 552 U.S. 38, 51 (2007) (noting that "improperly calculating[ the Guidelines range" is a reversible "procedural error" under Booker-Rita reasonableness review). Before Booker, when the district court applied the Guidelines provisions authorizing a departure from the otherwise-applicable Guidelines sentence, that decision was, prior to 2003, reviewed for abuse of discretion; after the PROTECT Act amendments in 2003, departures were reviewed de novo. See Rita v. United States, 551 U.S. 338, 360-67 (2007) (Stevens, J., concurring) (describing and discussing review of outside-Guidelines sentences under Koon v. United States, 518 U.S. 81 (1996), the 2003 amendments, and Booker).

Additionally, to the extent the correctness of a judge's finding of fact is itself in question on appeal, the "clearly erroneous" standard of appellate review applies, both before and after Booker. See Rita, 551 U.S. at 361-62 (Stevens, J., concurring) (noting that "[c]ritically, we did not touch the portions of $\S 3742(\mathrm{e})$ requiring appellate courts to . . ' 'accept the findings of fact of the district court unless they are clearly erroneous' .... By leaving those portions of the statute intact while severing the portion mandating a de novo standard of review, Booker restored the abuse-of-discretion standard identified in [Koon]."(quoting Booker, 543 U.S. at 271)); see also Gall, 552 U.S. at 51 (noting that "selecting a sentence based on clearly erroneous facts" is a reversible "procedural error" under Booker-Rita reasonableness review). For additional discussion of standards of review on appeal before and after Booker, see Hessick \& Hessick, supra note 15, at 4-28. 
now advisory for district court judges, who were to rely on the Guidelines only as one consideration among a list of statutorily-prescribed factors when determining a defendant's sentence. ${ }^{86}$ In addition, the remedial majority held that sentences imposed pursuant to this altered Guidelines sentencing regime would be reviewed under a "reasonableness" standard on appeal. ${ }^{87}$

2. Advisory Guidelines and Reasonableness Review under Booker-Rita

The Court's decision in Booker not only crafted a remedy to avoid the Blakely violations inherent in the mandatory Guidelines, but it also fundamentally changed the way federal sentencing analysis is performed in both district courts and on appeal. Prior to Booker, the Guidelines analysis was essentially the same at both levels: the district court calculated and imposed a sentence pursuant to the Guidelines, and the appellate courts determined whether that calculation involved any reversible error. ${ }^{88}$ After Booker, and after the Court's clarifying explanations in Rita, district courts and appellate courts must analyze sentencing in very different ways.

The district court must begin by calculating the Guidelines sentence. Although the result of this calculation no longer has mandatory effect, performing the Guidelines calculation remains a necessary first step in sentencing to ensure the Guidelines retain their advisory effect under the federal sentencing statutes as interpreted by the Booker remedial majority. ${ }^{89}$ Thus, in every case the court must consider the advice offered by the Guidelines, even if the judge decides to reject that advice and impose a different sentence. ${ }^{90}$

Next, the district court looks beyond the Guidelines and also considers the list of statutory factors in $\S 3553(\mathrm{a}){ }^{91}$ These factors are: "(1) offense and offender characteristics; (2)

86. See United States v. Booker, 543 U.S. 220, 245, 259-60 (2005).

87. See id. at 260-65.

88. See supra note 85; see also Hessick \& Hessick, supra note 15 , at 5-7 (describing appellate review of sentences imposed under pre-Booker mandatory Guidelines).

89. See Gall, 552 U.S. at 49 ; Rita, 551 U.S. at 338.

90. See, e.g., Gall, 552 U.S. at 50.

91. See id. at 49-50; Rita v. United States, 551 U.S. 338, 342-45 (2007). 
the need for a sentence to reflect the basic aims of sentencing, namely (a) 'just punishment' (retribution), (b) deterrence, (c) incapacitation, (d) rehabilitation; (3) the sentences legally available; (4) the Sentencing Guidelines; (5) Sentencing Commission policy statements; (6) the need to avoid unwarranted disparities; and (7) the need for restitution." 92 The statute directs that, in consideration of all the factors, the sentence imposed must be "sufficient, but not greater than necessary" to serve the purposes of punishment in factor (2).$^{93}$ Significantly, the Rita Court emphasized that district judges should not accord the Guidelines' advice any special weight, nor should they apply presumptive appropriateness to them. ${ }^{94}$ Instead, the Guidelines calculation is only one component of the $\S 3553(\mathrm{a})$ analysis and is no different than the other factors. If the court, in assessing those factors together with the Guidelines sentence, concludes that the advice of the Guidelines is sound, then the court likely will impose a sentence within the Guidelines range. ${ }^{95}$ On the other hand, if the court concludes the $\S 3553$ (a) factors diverge from the Guidelines, then the court may reject the Guidelines' advice and impose a different sentence. ${ }^{96}$ In either situation, the court must give its reasons for imposing the selected sentence. When the court accepts the advice of the Guidelines its explanation frequently will be short, because the judge agrees that the case is a typical one and

92. Id. at 347-48 (paraphrasing 18 U.S.C. $\$ 3553$ (a) (2006)).

93. 18 U.S.C. $\$ 3553(a)$ (2006); see also Rita, 551 U.S. at 347-48.

94. In Rita, the Court emphasized that "the presumption before us is an appellate court presumption," not one used by district courts. See Rita, 551 U.S. at 351; see also Kimbrough v. United States, 552 U.S. 85, 113-14 (2007) (Scalia, J., concurring)

If there is any thumb on the scales; if the Guidelines must be followed even where the district court's application of the $\S 3553(\mathrm{a})$ factors is entirely reasonable; then the 'advisory' Guidelines would, over a large expanse of their application, entitle the defendant to a lesser sentence but for the presence of [extraverdict facts]. This, as we said in Booker, would violate [the Apprendi doctrine.]

Id. The Court reiterated the point in a 2009 per curiam opinion. See Nelson v. United States, 129 S. Ct. 890, 891 (2009) (per curiam).

95. See Rita, 551 U.S. at 355-56 ("WW]here the judge and Commission both determine that the Guidelines sentence is an appropriate sentence for the case at hand, that sentence likely reflects the $\S 3553$ (a) factors. ...").

96. See id. at 350-51 (describing reasons why a district judge might reject a Guidelines advisory sentence). 
therefore warrants a typical sentence. ${ }^{97}$ When the court rejects the advice of the Guidelines, a more lengthy explanation may be needed to enable the appellate courts to assess whether the sentence selected was permissible. ${ }^{98}$

On appeal, the appellate court determines whether the sentence imposed was "reasonable" in light of the $\S 3553(\mathrm{a})$ factors. In Booker, the remedial majority could only infer statutory support for the "reasonableness" standard, ${ }^{99}$ and it did not provide any especially helpful definition of the standard. ${ }^{100}$ In Rita, the Court clarified that "appellate 'reasonableness' review merely asks whether the trial court abused its discretion." ${ }^{101}$ The Court's subsequent decisions applying Booker-Rita reasonableness review have repeated this clarification in upholding district courts' sentences as not abuses of discretion. ${ }^{102}$ In Gall, however, the Court reaffirmed traditional appellate-review principles by further clarifying that a "significant procedural error"-including "failing to calculate (or improperly calculating) the Guidelines range"-is inherently an abuse of discretion subject to reversal. ${ }^{103}$ Only after concluding that the district court's sentence is free from procedural defects, then, does the appellate court proceed to review the substantive question of whether the sentence imposed was an abuse of discretion. ${ }^{104}$

97. See id. at $357-58$.

98. See id.

99. Compare United States v. Booker, 543 U.S. 220, 261 (2005) ("[W]e read the statute as implying this appellate review standard. ..."), with .id.at 308-10 (Scalia, J., dissenting) ("The Court's needs to supplement the text that remains after severance suggests that it is engaged in redrafting the statute rather than just implementing the valid portions of it." (quoting Unites States v. Treasury Employees, 513 U.S. 454, 479 (1995))).

100. Compare Booker, 543 U.S. at 262-63 (“[W]e think it fair ... to assume judicial familiarity with a 'reasonableness' standard" for sentencing appeals), with id. at 310-13 (Scalia, J., dissenting) ("Indeed, the very concept of having a unitary standard of review for all kinds of appeals . . . finds no support in statutory language or established practice of the last two decades.").

101. Rita v. United States, 551 U.S. 338, 351; see also id. at 360-64 (Stevens, J., concurring).

102. See Gall v. United States, 552 U.S. 38, 51-52 (2007); Kimbrough v. United States, 552 U.S. 85, 111 (2007); Spears v. United States, 129 S. Ct. 840, 842 (2009) (per curiam).

103. See Gall, 552 U.S. at 51; see also Priester, supra note 9, at $255 \mathrm{n} .198$ (citing cases on traditional abuse of discretion standard).

104. See Gall, 552 U.S. at 51; see also id. at 56 ("Since the district court committed no procedural error, the only question for the Court of Appeals was whether the sentence was reasonable-i.e., whether the District Judge abused 
In doing so, the appellate court does not conduct its own independent evaluation of the value of the Guidelines' advice or the relative significance of the other $\S 3553(\mathrm{a})$ factors on the facts of the case, but rather evaluates only whether the sentence imposed by the district court is a reasonable application of $\S 3553(\mathrm{a})$ in the aggregate. ${ }^{105}$

Just as in the district courts, the Guidelines are only one component of the appellate court's assessment of whether the sentence imposed constitutes an abuse of discretion. After Booker, some of the circuits had adopted a presumption that a sentence imposed within the advisory Guidelines range was reasonable. ${ }^{106}$ Similarly, several circuits had adopted a principle that a sentence varying from the advisory Guidelines range had to be justified by an explanation proportionately persuasive to the degree of the variance. ${ }^{107}$ The Court allowed the former presumption, but rejected the latter principle.

In Rita, the Court found that an appellate presumption of reasonableness for a within-Guidelines sentence was permissible. Rita was convicted on five counts, including perjury, false statements, and obstruction of justice, for which the Guidelines sentence range was thirty-three to forty-one months. ${ }^{108}$ The district judge considered Rita's arguments for leniency, but concluded that a thirty-three month sentence best satisfied the $\S 3553$ (a) factors. ${ }^{109}$ When Rita appealed, arguing his sentence should have been even lower, the court of appeals upheld the sentence, concluding that Rita had not rebutted the presumption that a within-Guidelines sentence was reasonable on the facts of his case. ${ }^{110}$ The Supreme Court affirmed, explaining that the appellate court's presumption was permissible not because the advice of the

his discretion in determining that the $\S 3553(\mathrm{a})$ factors supported a sentence of probation and justified a substantial deviation from the Guidelines range."). But see Hessick \& Hessick, supra note 15, at 14-36 (arguing that Booker-Rita reasonableness review is substantially different than traditional abuse of discretion review).

105. See Gall, 552 U.S. at 51 ("The fact that the appellate court might reasonably have concluded that a different sentence was appropriate is insufficient to justify reversal of the district court.").

106. See Rita, 551 U.S. at 346.

107. See Gall v. United States, 552 U.S. 38, 45 (2007).

108. See Rita v. United States, 551 U.S. 338, 341-45 (2007).

109. See id. at 344-46.

110. See id. at 345-46. 
Guidelines carries special weight, but because a withinGuidelines sentence reflects the double agreement of the district judge and the Sentencing Commission that the sentence imposed is consistent with the $\S 3553(\mathrm{a})$ factors. ${ }^{111}$ So long as the presumption is genuinely rebuttable, it preserves the advisory nature of the Guidelines consistent with the Booker merits holding. ${ }^{112}$

The Rita Court also underscored that the converse was not true: an appellate court must not presume that a sentence outside the Guidelines is unreasonable, because under Booker the district court is entitled to disagree with the Commission's application of the $\S 3553(\mathrm{a})$ factors. ${ }^{113}$ The Court reaffirmed this principle in Gall by invalidating the use of proportionality review. ${ }^{114}$ Gall pled guilty to conspiracy to distribute ecstasy, an offense he had committed about four years earlier while a college student. ${ }^{115}$ Although the Guidelines range was thirty to thirty-seven months, the judge sentenced Gall to only three years probation, citing circumstances such as Gall's age and immaturity at the time of the offense, his voluntary withdrawal from the conspiracy, and his self-rehabilitation and good works after leaving the conspiracy. ${ }^{116}$ When the Government appealed the sentence as too lenient, the court of appeals reversed; it described the sentence as "a 100\% downward variance" from the Guidelines and assessed the cited circumstances as inadequately persuasive to justify such a steep difference from the Guidelines' advice. ${ }^{117}$ The Court rejected this analysis, explaining that abuse of discretion review of the district court's application of the $\S 3553$ (a) factors applies across the full punishment range, and that the application of the factors does not countenance heightened standards of review, even

111. See id. at 347 ("[T]he presumption reflects the fact that, by the time an appeals court is considering a within-Guidelines sentence on review, both the sentencing judge and the Sentencing Commission will have reached the same conclusion as to the proper sentence in the particular case.").

112. See id. at 350-55; see also id. at 363-67 (Stevens, J., concurring).

113. See id. at 355.

114. See Gall v. United States, 552 U.S. 38, 41 (2007). The Court originally had granted certiorari to resolve this question in the same Term as Rita, but "the case was mooted by [the defendant's] untimely death." See id. at 40-41 (discussing United States v. Claiborne, 551 U.S. 87 (2007)).

115. See id. at 41-43.

116. See id. at $43-45$.

117. See id. at $45-46$. 
for outlier sentences. ${ }^{118}$ Thus, an outlier sentence may be reversed if it constitutes an abuse of discretion, but the degree of difference from the advisory Guidelines range does not carry special weight in making that conclusion. ${ }^{119}$

Finally, in Kimbrough the Court emphasized the primacy of the $\S 3553(\mathrm{a})$ factors in federal sentencing under the Booker-Rita regime. Kimbrough pled guilty to narcotics offenses involving specific quantities of both crack and powder cocaine. ${ }^{120}$ Accordingly, his crimes implicated the long-controversial "100:1 ratio" applicable in cocaine offenses. ${ }^{121}$ In both the three tiers of the offense-defining statute, 21 U.S.C. $\S 841$ (2006), and the numerous gradations of the implementing Guidelines sentencing provision ( $\S$ 2D1.1), a given quantity of crack cocaine is comparable to an amount of powder cocaine one hundred times larger. ${ }^{122}$ Under the Guidelines, Kimbrough's advisory sentence range was 228-270 months; based on a 1:1 ratio, it would have been ninety-seven to 106 months. ${ }^{123}$ Bound by the governing statutory mandatory minimum sentences, the judge sentenced Kimbrough to 180 months' imprisonment. ${ }^{124}$ When the Government appealed the sentence as too low, it won in the court of appeals but lost in the Supreme Court. ${ }^{125}$ The Kimbrough Court rejected the Government's argument that the 100:1 ratio was a congressionally-mandated sentencing policy that the sentencing judge had no authority to ignore, even under Booker-Rita sentencing. ${ }^{126}$ The Court conceded that the ratio appeared in the offense-defining statute, but argued that its placement there only codified minimum and maximum sentences for the three offense tiers, and was not an implicit command for the scaling of all cocaine sentences

118. See id. at 46-49 (stating that "applying a heightened standard of review to sentences outside the Guidelines range . . . is inconsistent with . . . the abuseof-discretion review. ...").

119. See id. at 51-52.

120. See Kimbrough v. United States, 552 U.S. 85, 91-92 (2007).

121. See id. at $94-100$ (describing the origin of ratio and controversy surrounding it).

122. See id. at 91.

123. See id. at $92-93$.

124. Id. at 93 . The mandatory minimum on three $\S 841$ counts was ten years (sentenced concurrently), plus a consecutive five-year mandatory minimum sentence on a § 924(c) count. See id. at 91-93 \& n.3.

125. See id. at $91,93$.

126. See Kimbrough v. United States, 552 U.S. 85, 101-03 (2007). 
by that ratio. ${ }^{127}$ That is, $\S 841$ did not codify a statutorilymandated exception to the otherwise-applicable \& 3553(a) analysis. $^{128}$ Consequently, the scaling of sentences by the ratio was advice from the Guidelines, which the district court was entitled to reject--"even in a mine-run case" like Kimbrough's. ${ }^{129}$ Two years later, in Spears, a per curiam opinion issued without oral argument, the Court reaffirmed its analysis in Kimbrough and explained that not only was a district court entitled to reject the advice of the Guidelines based on a policy disagreement with them, but the court also was entitled to substitute its own ratio which it believed better served the factors in the $\S 3553(\mathrm{a})$ analysis. ${ }^{130}$

\section{The Future of Booker-Rita Reasonableness Review}

To some extent, of course, the future of Booker-Rita reasonableness review rests in the hands of Congress. Although any statutory amendments would have to comply with Blakely, lest the Court invalidate them as well, Congress does have a number of options at its disposal. The most radical would be to repeal the Guidelines entirely and abolish the Sentencing Commission, thus restoring sentencing to the domain of Article III judges. Given Congress' repeatedly expressed concern with systemic uniformity, however, this seems to be unlikely. But it could become more plausible if the Guidelines were to be replaced with data-collection and information-sharing mechanisms to facilitate greater consistency among judges. ${ }^{131}$ Another alternative would be to reject the conclusion of the Booker remedial majority, and to ratify the conclusion of the Booker remedial dissent: enacting legislation to "Blakely-ize" Guidelines facts into verdict facts, either for all Guidelines facts in all cases or simply for those

127. See id. at 102-03.

128. See id. at 102, 108-10.

129. See id. at 109-10.

130. See Spears v. United States, 129 S. Ct. 840, 841-45 (2009).

131. See Marc L. Miller, A Map of Sentencing and a Compass for Judges: Sentencing Information Systems, Transparency, and the Next Generation of Reform, 105 COLUM. L. REv. 1351 (2005); Marc L. Miller \& Ronald F. Wright, "The Wisdom We Have Lost": Sentencing Information and Its Uses, 58 STAN. L. REV. 361 (2005); see also, e.g., Max M. Schanzenbach \& Emerson H. Tiller, Reviewing the Sentencing Guidelines: Judicial Politics, Empirical Evidence, and Reform, 75 U. CHI. L. REV. 715 (2008); Michael A. Wolff, Missouri's InformationBased Discretionary Sentencing System, 4 OHIO ST. J. CRIM. L. 95 (2006). 
facts required to be verdict facts under Blakely in each particular case. ${ }^{132}$ To date, however, Congress has shown little interest in responding to the Court's decisions with new legislation, ${ }^{133}$ leaving Booker-Rita reasonableness review in place for the foreseeable future.

On the Court itself, Booker-Rita reasonableness review appears to have gained a solid footing. Although the Booker remedial question was decided five-to-four in 2005, the majority opinions in Rita, Gall, and Kimbrough each were joined by at least seven justices. ${ }^{134}$ The prospect of radical revision to the Booker-Rita sentencing regime in future decisions of the Court, then, is probably not very great.

Nonetheless, two strong criticisms of Booker-Rita reasonableness review persist within the separate opinions in these cases. One is the challenge raised by Justice Scalia, arguing that even some Booker-Rita-compliant sentences are unconstitutional as-applied to the extent they can only be upheld as reasonable on appeal due to the district court's reliance on extraverdict facts to justify a lengthier sentence than would be permissible on the verdict facts alone. ${ }^{135}$ The solution, Justice Scalia maintains, is to vest complete substantive sentencing discretion in the district courts, such that the verdict facts alone are always adequate to justify any sentence up to the Apprendi-Blakely maximum. ${ }^{136}$

132. See, e.g., Stephen L. Chanenson, The Next Era of Sentencing Reform, 54 EMORY L.J. 377, 430-32 (2005); see also United States v. Booker, 543 U.S. 220, 277-80, 287, 299, 301-03 (2005) (Stevens, J., dissenting); id. at 324-26 (Thomas, J., dissenting). See also Gall v. United States, 552 U.S. 38, 60-61 (2007) (Souter, J. concurring) ("I continue to think that the best resolution . . . would be a new Act of Congress: reestablishing a statutory system of mandatory sentencing guidelines ... but providing for jury findings of all facts necessary to set the upper range of sentencing discretion.").

133. See, e.g., Peter J. Henning, Prior Good Works in the Age of Reasonableness, 20 FED. SENT'G. REP. 187, 188 (2008) (“Congress has not yet responded to Booker by adopting a legislative fix that would curtail judicial sentencing discretion ....").

134. See infra Part II.C.

135. See supra Part II.A.3.

136. See Rita v. United States, 551 U.S. 338, 362-84 (2007) (Scalia, J., concurring). Specifically, Justice Scalia argued that appellate courts should conduct only procedural review of the district court's sentencing, without any review of the substantive merits of the sentence imposed. See id. at 369-70, 373-75 (Scalia, J., concurring). In Gall and Kimbrough, Justice Scalia accepted substantive review under Rita as statutory stare decisis. See Kimbrough v. United States, 552 U.S. 85, 112-14 (2007) (Scalia, J., concurring); Gall, 552 U.S. at 60 (Scalia, J., concurring). 
Furthermore, if such a solution is necessary to sustain the constitutionality of lengthy sentences, then the district courts must be granted equal authority to impose lenient sentences, because the statutes enacted by Congress cannot fairly be interpreted to provide for differential standards on the high and low ends. ${ }^{137}$ Although to date Justice Scalia's analysis has not been joined by other justices, his influential role in prior Apprendi doctrine cases gives pause to dismiss his argument too quickly. ${ }^{138}$

The other challenge to Booker-Rita reasonableness review comes from Justice Thomas. Unlike the other three justices from the Booker remedial dissent, he stands alone in refusing to accept the legitimacy of reasonableness review even with the clarifications provided by Rita. ${ }^{139}$ In his dissent in Kimbrough, Justice Thomas criticized the majority's application of reasonableness review as legislating policy, not interpreting law-an illegitimate usurpation of legislative power by the Court. ${ }^{140}$ To bring the courts back within their proper role, he argues that the Guidelines should be enforced as mandatory to the maximum extent constitutionally possible; ${ }^{141}$ in Gall and Kimbrough, this would mean

137. See Rita, 551 U.S. at 373 n.2 (Scalia, J., concurring) (citing Booker, 543 U.S. at 257-58, and arguing that "since reasonableness review should not function as a one-way ratchet, we must foreswear the notion that sentences can be too low in light of the need to abandon the concept that sentences can be too high.").

138. See supra note 53 (discussing Justice Scalia's role). Interestingly, Justice Thomas initially joined Justice Scalia's analysis concurring in Rita, but then changed his mind and dissented in Gall and Kimbrough. See Kimbrough, 552 U.S. at 116 (Thomas, J., dissenting) ("Although I joined Justice Scalia's dissent in Rita accepting the Booker remedial opinion as a matter of 'statutory stare decisis,' I am now convinced that there is no principled way to apply the Booker remedy ... ."); see also Gall v. United States, 552 U.S. 38, 61 (Thomas, J., dissenting).

139. See Kimbrough, 552 U.S. at 114-16 (Thomas, J., dissenting); see also Gall, 552 U.S. at 61 (Thomas, J., dissenting).

140. See Kimbrough, 552 U.S. at 114-16 (Thomas, J., dissenting).

141. See id. at 116 (Thomas, J., dissenting) ("I think it is best to apply the statute as written, including 18 U.S.C. $\S 3553(\mathrm{~b})$, which makes the Guidelines mandatory."). In light of Justice Thomas' analysis in writing the dissenting opinion in Harris, however, his argument in Kimbrough "seems more strategic than genuine." Priester, Canine Metaphor, supra note 9, at 266 n.238. That is, because Justice Thomas believes Apprendi should apply to mandatory minimum sentences as well as increased maximum sentences, and consequently he would extend the constitutional reach of Booker to the low end of Guidelines ranges, his position in Kimbrough is only viable under the Court's existing decisions, and not Justice Thomas's own view on the Apprendi doctrine. Id. 
reversing the defendant's sentences for the statutory error of unauthorized leniency from the Guidelines. ${ }^{142}$ Thus, he rejects Justice Scalia's argument based on a legislative goal of statutory symmetry: Justice Thomas would enforce the Guidelines on the low end while invalidating them on the high end (unless the relevant Guidelines facts were established as verdict facts). ${ }^{143}$ As with Justice Scalia's criticism of reasonableness review, to date Justice Thomas' criticism has not been joined by any other justice-but also like Justice Scalia, Justice Thomas has written several highly influential opinions in prior Apprendi doctrine cases. ${ }^{144}$ His view too, then, must be taken seriously.

\section{The Tangled Threads of the Justice's Doctrinal Positions}

If the scope and ramifications of the Apprendi doctrine and Booker-Rita reasonableness review seem overly complicated and insufficiently reasoned, at least it is not difficult to determine how this confounding reality has come about through the Court's decisions. From its origin, this line of cases has been exemplified by alliances that not only are atypical among the justices, but also constantly shift in their membership. It is no surprise, then, that the current Court appears to have no fewer than six different perspectives on Apprendi and Booker among the eight justices who have participated in the decisions to date.

The constitutional principle that became the Apprendi doctrine first took shape in two 1998 dissents by Justice Scalia. In these dissents, joined by Justices Stevens, Ginsburg, and Souter, he argued that the defendants' sentences, enhanced due to recidivism, were unconstitutional because the requisite facts-the prior convictions-had not been established as verdict facts in the jury trial. ${ }^{145}$ The

142. See Kimbrough v. United States, 552 U.S. 85, 116 (Thomas, J., dissenting) ("Applying the statute as written, it is clear that the District Court erred by departing below the mandatory Guidelines range."); see also Gall, 552 U.S. at 61 (Thomas, J., dissenting).

143. This result is the consequence of Justice Thomas's votes in Kimbrough and Gall on the one hand, and in Booker on the other, respectively.

144. See Harris v. United States, 536 U.S. 545, 572-80 (2002) (Thomas, J., dissenting); Apprendi v. New Jersey, 530 U.S. 466, 499-523 (2000) (Thomas, J., concurring).

145. See Monge v. California, 524 U.S 721, 739-41 (1998) (Scalia, J., dissenting); Almendarez-Torres v. United States, 523 U.S. 224, 248-49, 258-60 
majority opinions, comprised of Chief Justice Rehnquist and Justices O'Connor, Kennedy, Thomas, and Breyer, upheld the sentences under a fundamental fairness analysis. ${ }^{146}$

The following year in Jones, Justice Thomas changed sides, persuaded by historical evidence about the correct originalist interpretation of the Sixth Amendment. ${ }^{147}$ His action formed the five-to-four bloc that adopted and developed the Apprendi doctrine from 2000-2005 in the cases of Apprendi, Ring, Blakely, and the merits opinion in Booker. ${ }^{148}$ In each of these cases, the remaining justices continued to dissent, rejecting the majority's Sixth Amendment analysis and arguing for fundamental fairness analysis in its place. ${ }^{149}$

The pro-Apprendi bloc fractured first in 2002, when Justice Scalia changed sides to uphold the mandatory minimum sentence in Harris. ${ }^{150}$ Now in dissent, his erstwhile allies insisted that the Apprendi doctrine should apply to both the bottom and top of the sentencing range. ${ }^{151}$ Despite being the controlling vote, Justice Scalia did not write separately to explain his reasons for interpreting the doctrine differently. ${ }^{152}$

The bloc splintered again in 2005, when Justice Ginsburg parted ways on the issue of the remedy to be ordered in

(1998) (Scalia, J., dissenting).

146. See Monge, 524 U.S. at 729; Almendarez-Torres, 523 U.S. at 247. For discussion of the fundamental fairness analysis followed by these Justices, see Priester, Canine Metaphor, supra note 9, at 228-30; Priester, Constitutional Formalism, supra note 18, at 292-96; Benjamin J. Priester, Sentenced for a "Crime" the Government Did Not Prove: Jones v. United States and the Constitutional Limitations on Factfinding by Sentencing Factors Rather Than Elements of the Offense, 61 LAW \& CONTEMP. PROBS. 249, 263-66 (1998) [hereinafter Priester, Sentenced].

147. See Jones v. United States, 526 U.S. 227, 230 (1999); see also Apprendi, 530 U.S. at 520-21 (Thomas, J., concurring) (explaining reasons for his changed vote and repudiating his vote in Almendarez-Torres).

148. Despite the persistence of this majority, however, the Court has not yet revisited the issue of recidivism sentence enhancements. See supra note 23.

149. See, e.g., Apprendi, 530 U.S. at 552-54 (O'Connor, J., dissenting); Ring v. Arizona, 536 U.S. 584, 613 (2002) (Kennedy, J., concurring); Blakely v. Washington, 542 U.S. 296, 320-23 (2004) (O'Connor, J., dissenting); United States v. Booker, 543 U.S. 220, 327-31 (2005) (Breyer, J., dissenting).

150. See Harris v. United States, 536 U.S. 545, 549 (2002).

151. See id. at 575-77 (Thomas, J., dissenting).

152. The plurality opinion by Justice Kennedy, however, relies on arguments previously advanced by Justice Scalia rather than the ones previously advanced by Justice Kennedy, suggesting that the plurality opinion in fact reflects Justice Scalia's views although he is not its author. See Priester, Canine Metaphor, supra note 9, at $233 \mathrm{n} .113$ (discussing and analyzing the Harris plurality opinion in this way). 
Booker. ${ }^{153}$ Although she was the controlling vote, Justice Ginsburg did not write separately to explain why she joined Justice Breyer's opinion, rather than Justice Stevens' or Justice Scalia's. ${ }^{154}$

By the time of the next round of cases in 2007, Chief Justice Roberts and Justice Alito had taken their seats on the Court. In Cunningham, both seemed to accept the existing decisions as a given. Chief Justice Roberts joined the bloc opinion applying Apprendi and Blakely by a six-to-three margin. ${ }^{155}$ While Justice Alito dissented, he analyzed the issue under the terms of the Booker remedial opinion, ${ }^{156}$ and he did not join Justice Kennedy's separate dissent that openly called for rejecting Apprendi and the Booker merits opinion. ${ }^{157}$

The three cases applying Booker reasonableness review in 2007 were nominally unremarkable eight-to-one decisions, but again the justices' underlying disagreements on the doctrine were readily apparent. In Rita, only Justice Souter rejected the notion of any presumption of reasonableness to a Guidelines sentence, ${ }^{158}$ but he subsequently joined the holdings in Gall and Kimbrough. ${ }^{159}$ Similarly, Justices Stevens and Ginsburg expressed concern in Rita that Booker reasonableness review must involve meaningfully deferential appellate review, ${ }^{160}$ but they subsequently wrote the opinions of the Court in Gall and Kimbrough, respectively. ${ }^{161}$ By contrast, Justice Scalia remained critical of Booker reasonableness review in all three cases, ${ }^{162}$ while Justice Thomas went further, openly calling for overruling the Booker remedial opinion. ${ }^{163}$ Among the other justices, Justice

153. See Booker, 543 U.S. at 225 n.***, 244 n.*.

154. See id. at 225 (listing opinions authored by Justices Stevens, Breyer, Scalia, and Thomas).

155. See Cunningham v. California, 549 U.S. 270, 273 (2007).

156. See id. at 297-311 (Alito, J., dissenting).

157. See id. at 295-97 (Kennedy, J., dissenting) ("In my view the Apprendi line of cases remains incorrect.").

158. See Rita v. United States, 551 U.S. 338, 391-92 (2007) (Souter, J., dissenting).

159. See Kimbrough v. United States, 552 U.S. 85, 90 (2007); Gall v. United States, 552 U.S. 38, 60-61 (2007) (Souter, J., concurring).

160. See Rita, 551 U.S. at 363-67 (Stevens, J., concurring).

161. See Kimbrough, 552 U.S. at 90; Gall, 552 U.S. at 39.

162. See supra note 136 (explaining the shift in Justice Scalia's arguments from Rita to Gall and Kimbrough).

163. See Kimbrough, 552 U.S. at 116 (Thomas, J., dissenting); see also supra note 138 (explaining shift in Justice Thomas' votes from Rita to Gall and 
Kennedy and Chief Justice Roberts joined Breyer's opinion, and all three of them also joined the holdings in Gall and Kimbrough without comment. ${ }^{164}$ But Justice Alito did not join them; instead, he argued that the Booker remedial opinion should be read to allow the Guidelines to carry "significant weight" in sentencing, a position none of the other justices accepted. ${ }^{165}$

The decision in Ice in 2009 may have signaled the end of any reliable voting bloc in this line of cases. The issue in Ice involved the factfinding that determined whether the sentences for multiple counts of conviction in the same verdict would run concurrently or consecutively. ${ }^{166}$ The Court ruled five-to-four that the judge could make that finding-but with a different alignment than in any prior decision in this line of cases. In dissent, Justice Scalia argued that Apprendi required jury factfinding, and his analysis was joined by Justices Thomas and Souter, as well as Chief Justice Roberts (who, consistent with his vote in Cunningham, appears ready to follow Apprendi). ${ }^{167}$ Unsurprisingly, Justices Kennedy, Breyer, and Alito voted to allow judicial factfinding. The decisive votes, then, came from Justice Ginsburg and Stevens, who rejected Justice Scalia's interpretation of the historical record and its implications for applying Apprendi to consecutive sentences. ${ }^{168}$ Unlike Booker, this time Justice Ginsburg wrote the opinion, explaining her divergence from Justice Scalia's view.

Examining these decisions in the aggregate reveals that the justices on the Court are deeply divided over the meaning and application of the Apprendi doctrine and Booker reasonableness review. In summary:

- Justice Scalia initiated and shaped the Apprendi doctrine, and maintains that Booker-Rita reasonableness review has not resolved the constitutional issue.

- Justice Thomas follows Scalia's Apprendi analysis but

\footnotetext{
Kimbrough).

164. See Kimbrough, 552 U.S. at 90; Gall, 552 U.S. at 39; Rita v. United States, 551 U.S. 338, 340 (2007).

165. Kimbrough v. United States, 552 U.S. 85, 116 (2007) (Alito, J., dissenting); Gall v. United States, 552 U.S. 38, 61-73 (2007) (Alito, J., dissenting).

166. See Oregon v. Ice, 129 S. Ct. 711, 714 (2009).

167. See id. at 720 (Scalia, J., dissenting).

168. See id. at $714,716-18$ (majority opinion).
} 
would expand it by overruling Harris, and rejects Booker-Rita reasonableness review entirely.

- Justice Stevens has voted with Justice Thomas on Apprendi questions except in Ice, but accepted Booker-Rita reasonableness review.

- Justice Ginsburg has taken the same positions as Stevens, except that she joined the Booker remedial majority instead of the remedial dissent.

- Chief Justice Roberts has joined opinions taking Scalia's position on the Apprendi doctrine (in Cunningham and Ice), but follows Breyer's position on Booker-Rita reasonableness review.

- Justices Breyer continues to oppose the Apprendi doctrine, but has taken the lead in shaping the nature of Booker-Rita reasonableness review.

- Justice Kennedy has voted with Breyer in every casethe only consistently stable alliance in the entire line of cases.

- Justice Alito would go even further than Breyer's version of Booker-Rita reasonableness review, allowing the Guidelines to be given even more influence at sentencing.

And of course, now Justices Souter and Stevens have retired, and Justices Sotomayor and Kagan have replaced them, leaving the future of the doctrine even more in motion than it already was.

\section{APPRENDI LAND AS BIZARRO WORLD: THE COURT'S SURREAL CONSTITUTIONAL DOCTRINE}

The Apprendi doctrine has been controversial from the very beginning, and it has only grown more controversial as the Court has expanded its scope to encompass BlakelyBooker analysis on merits issues and Booker-Rita reasonableness review on remedial issues. If the Court takes the doctrine even further, such as by officially recognizing asapplied challenges or by overruling Harris, even more grounds for criticism would arise.

There are many possible angles to examine in evaluating and critiquing the Court's version of the Apprendi doctrine. In prior articles, I emphasized two major conceptual attacks on the Court's reasoning and holdings. Each of these continues to provide a helpful perspective for illustrating the significant flaws in the path the Court has taken.

In Structuring Sentencing, I criticized the Court's 
reliance on the Jury Trial Clause of the Sixth Amendment, and argued that the better conceptual justification for the Apprendi doctrine was the constitutional structure of criminal procedure. ${ }^{169}$ While the Court is correct to note the important roles played by juries in adjudicating guilty and not guilty verdicts in criminal cases, and by judges in determining the sentence imposed upon conviction, in developing the Apprendi doctrine the Court has lost sight of the important roles played by other actors in determining the defendant's offense and punishment. ${ }^{170}$ In particular, the offense of conviction depends not merely upon a jury verdict or guilty plea, but also is a product of the statutes enacted by the legislature and the charges filed by the prosecutor. ${ }^{171}$ Similarly, although the judge is the actor who directly imposes sentence, that authority is constrained not merely by the scope of the jury's verdict or counts admitted in the plea, but also by the scope of punishment authorized in the statutory offenses and the prosecution's charges. ${ }^{172}$ In viewing the issue as simply one about the allocation of power between jury and judge, therefore, the Court has given far too little consideration to the full context surrounding a criminal conviction, and the division of power among four, not two, institutions in the constitutional structure of criminal procedure. ${ }^{173}$

In The Canine Metaphor, I proposed a tripartite analytical framework for assessing relationships of power and allocations of authority over criminal sentencing, separating the process of determining an individual defendant's sentence into three stages. ${ }^{174}$ The first stage is the adjudication of verdict facts, which at a minimum is constitutionally necessary to determine the defendant's offense of conviction. ${ }^{175}$ The second stage is the adjudication of additional, extraverdict sentencing facts that might be deemed relevant to determining the appropriate punishment but do not operate to convict the defendant of an aggravated

169. See Priester, Structuring Sentencing, supra note 10, at 885-935.

170. See id. at 891-95.

171. See id. at 891-902.

172. See id. at 891-95, 902-09.

173. See id. at 891-95, 928-34.

174. See Priester, Canine Metaphor, supra note 9, at 226-27.

175. See id. at 227-34. 
offense. ${ }^{176}$ The third stage involves the determination of the normative value of all the various adjudicated facts, by assessing how much each fact is worth and aggregating the facts and their respective weights into an ultimate punishment for the offender. ${ }^{177}$ In developing the Apprendi doctrine as it has, the Court has gone astray in at least two significant ways in light of this tripartite framework. For one, the Court has shifted certain factfinding from the second stage into the first stage, even though the extraverdict factfinding did not alter the offense of conviction. ${ }^{178}$ For another, the Court has asserted exclusively judicial power over third stage determinations of the normative value of facts in imposing sentence, without providing an adequate constitutional justification for prohibiting legislative involvement in those determinations. ${ }^{179}$ In its most recent decisions, the Court has only compounded these problems.

\section{A. Exacerbating the Flaws: Making Even Less Sense Than Before}

When the Court expanded the Apprendi doctrine to encompass Blakely-Booker and the invalidation of mandatory sentencing-regulating provisions that increase maximum sentences, it introduced several significant flaws into its new constitutional law of sentencing. One major flaw was that the Court created an absurd formalism in which the identical finding of fact, with the identical effect on the sentence, would sometimes be constitutional and would sometimes be unconstitutional. ${ }^{180}$ Another flaw was that the Court's analysis lost its foundation in the jury's role in the constitutional structure of criminal procedure, instead focusing on the judge's role in deciding a defendant's fate. ${ }^{181}$ Ultimately, the Court imposed its own perspective on optimal sentencing policy as mandates of constitutional law, when in fact those policy questions are highly contestable and are not resolved by the Constitution. ${ }^{182}$

176. See id. at 227, 234-40.

177. See id. at $227,240-52$.

178. See id. at 227-240, 252-62.

179. See id. at $240-59,262-69$.

180. See Priester, Canine Metaphor, supra note 9, at 222-24.

181. See id. at 224-26.

182. See id. at 260-69. 
Rather than correcting these doctrinal flaws, the Court's subsequent cases not only have exacerbated them, but also introduced even more flaws into the Apprendi doctrine. Although it might not have seemed possible five years ago, unfortunately the Apprendi doctrine now makes even less sense than it did before.

\section{The Formalistic Absurdities Get More Absurd}

The first significant flaw in the Court's current version of the Apprendi doctrine is that it relies upon a formalism that produces absurdly inconsistent outcomes. Under the Court's doctrine, the constitutionality or unconstitutionality of functionally identical extraverdict findings of fact will depend solely on the Court's formalistic line, not upon any predictable or identifiable criteria delimiting the sentence imposed upon the defendant.

Of course, the original version of the Apprendi doctrine was based on a formalistic rule: an increased sentence based on an extraverdict fact is unconstitutional if it exceeds the maximum sentence available under the statutory offense of conviction by reference to the verdict facts. The dissent in Apprendi criticized this rule as a "meaningless formalism" and argued that the statutory offense of conviction carried no special constitutional significance so long as the punishment imposed was authorized by any applicable sources of law. ${ }^{183}$ This argument was properly rejected by the majority because enforcing the maximum punishment authorized by the offense of conviction is necessary to protect the jury's role in the constitutional structure of criminal procedure. ${ }^{184}$ Thus, the Apprendi doctrine rightfully concludes that, for example, upon conviction under a burglary statute with a maximum sentence of ten years, there is a constitutionally important distinction between extraverdict factfinding that increases the sentence from four years to six years on the one hand, and from nine years to eleven years on the other. The distinction between those two instances of extraverdict factfinding is formalistic, but it is a formalism which preserves core

183. Apprendi v. New Jersey, 530 U.S. 466, 539 (2000) (O'Connor, J., dissenting) (describing the rule adopted in the majority opinion as "a meaningless formalism"). See Priester, Structuring Sentencing, supra note 10, at 876, 897; see also Priester, Canine Metaphor, supra note 9, at 228-30.

184. See Priester, Structuring Sentencing, supra note 10, at 896-902. 
constitutional principles.

The merits analysis of Blakely and Booker created the doctrine's absurd ramifications when it adopted the broader formalism: an increased sentence based on an extraverdict fact is unconstitutional if it exceeds the maximum sentence available under non-offense defining provisions of law, whether statutory (as in Blakely) or non-statutory (as in Booker), by reference to the verdict facts. Because this broader formalism treats differently instances of functionally identical extraverdict factfinding that relate only to calculating the sentence within the scope of the offense of conviction, its application produces two principal absurdities.

One absurdity is intra-jurisdictional: the same finding of fact with the same sentencing effect will be constitutional in some cases but unconstitutional in others, even when the sentence in all those cases is within the scope of the offense of conviction. ${ }^{185}$ For example, suppose the sentencing judge makes an extraverdict finding that the defendant discharged a firearm while committing his bank robbery crime, a statutory offense of conviction carrying a maximum of twenty-five years. A separate sentencing-regulating provision, like the federal Guidelines, mandates that the judge add four years to the sentence, increasing the sentence imposed from twelve years to sixteen years. Under BlakelyBooker, that mandatory increase is unconstitutional if the verdict facts authorized a maximum sentence of fifteen years under the Guidelines, but constitutional if they authorized a maximum sentence of twenty years under the Guidelinesdespite the fact that the verdict facts also established an offense of conviction authorizing up to twenty-five years in every case.

The other absurdity is inter-jurisdictional: the same finding of fact with the same sentencing effect will be constitutional in some states but not in others. ${ }^{186}$ That is, if a mandatory sentencing-regulating provision required the judge to add four years and expand the top end of the defendant's otherwise available sentence, then Blakely. Booker is violated. In another state with purely discretionary sentencing, however, a sentencing judge may choose to make

185. See Priester, Canine Metaphor, supra note 9, at 223.

186. See id. at 222-23. 
the extraverdict factfinding of discharging a firearm, and choose to assign a four year increase to that fact, and yet Blakely-Booker will not be violated.

In the Court's subsequent decisions applying its Booker remedial analysis, each of these absurdities produced by the Court's formalism has only gotten worse. It is difficult to see how the Apprendi doctrine can survive in its current form when the Court persists in allowing such profound flaws to remain embedded deep in its core.

The intra-jurisdictional absurdities produced by BookerRita reasonableness review are probably starker, simply because they are so bizarre. The consequence of this form of appellate review is that the identical extraverdict fact with the identical effect on the defendant's sentence will be reversed in cases where the appellate court concludes the sentence imposed was an abuse of discretion, but affirmed in cases where the appellate court concludes the sentence imposed was reasonable on the facts of the case. ${ }^{187}$ For example, if the appellate court concludes that the sixteen year sentence for bank robbery was unreasonably high compared to the verdict facts alone, then the four year increase for extraverdict discharging will be reversed-but if the appellate court concludes that sixteen years was reasonable for the verdict facts, then the four years added by extraverdict factfinding will be upheld. Whether the extraverdict factfinding was permissible will vary from case to case depending on the appellate court's judgment about whether the sentence imposed was reasonable, or instead an abuse of discretion.

What makes this result all the more absurd, of course, is that the line between permissible and impermissible sentences is not something which can be calculated or identified in advance, but rather is a roving demarcation contingent on the ad hoc judgments of panels of appellate judges. At least under Blakely-Booker it is possible for a trial judge to map over the verdict facts onto mandatory sentencing-regulating provisions as well as offense-defining statutes, and thereby figure out the relevant Blakely-Booker maximum sentence. By contrast, under Booker-Rita reasonableness review the trial judge will only find out later

187. See supra Part II.B.1 (explaining Booker-Rita reasonableness review). 
whether his sentence calculation was permissible. Moreover, the trial judge may receive divergent feedback from the appellate courts for functionally identical situations. For example, a four year sentencing addition for discharging a firearm may be upheld as reasonable when increasing the sentence from twelve to sixteen years for a bank robbery conviction, but reversed as an abuse of discretion when increasing from three years to seven years on a lesser charge, such as robbery of a postal carrier. ${ }^{188}$

The problem becomes even more apparent when applying Justice Scalia's position that maintains the operation of appellate review can itself create as-applied Blakely-Booker violations. ${ }^{189}$ Under his view, the constitutionally relevant maximum sentence is created not only by offense-defining statutes and mandatory sentencing-regulating provisions together, but also by any decision of an appellate court that concludes a sentence would not be permissible but for the presence of certain facts to justify it. That is, extraverdict factfinding does not raise as-applied constitutional concerns if it only helps to explain why the trial judge selected the particular sentence that he did from among the scope of options on the table; however, if the fact was necessary to authorize the sentence, in the sense that its finding was required to avoid reversal, then it must be proven as a verdict fact. ${ }^{190}$ To illustrate by returning to the example, if the sixteen year sentence for bank robbery would be upheld even without relying on a four year increase specifically attributable to discharging a firearm, then extraverdict factfinding was constitutional-but if the sixteen year sentence would be deemed an abuse of discretion absent the fact of discharging, then extraverdict factfinding was unconstitutional.

Ironically, then, extraverdict factfinding is unconstitutional if it matters, and constitutional only if it is superfluous. The doctrine has become absurdly formalistic when the identical finding of fact, with the identical effect on

188. Compare 18 U.S.C. $\S 2113$ (2006) (punishing the offense of bank robbery by up to twenty-five years' imprisonment), with 18 U.S.C. $\$ 2115$ (2006) (punishing offense of robbery of a postal carrier by up to five years' imprisonment).

189. See supra Part II.A.3 (discussing Justice Scalia's position).

190. See supra notes 56-60 and accompanying text. 
the sentence, has varying constitutionality depending on the appellate court's ad hoc assessment of reasonableness: if the court affirms the sentence then the extraverdict factfinding was constitutional, but if it reverses the sentence then the extraverdict factfinding was unconstitutional. In other words, Justice Scalia's position converts every sentencing increase deemed an abuse of discretion from a reversible error into a constitutional error by the trial court.

Finally, the Court's applications of Booker-Rita reasonableness review illustrate the continuing interjurisdictional absurdities produced by the Court's formalism, as well. For one thing, the Court's cases mean that states with advisory guidelines or presumptive sentences will have to implement deferential standards of appellate review comparable to federal Booker-Rita reasonableness review to avoid the equivalent Blakely-Booker concerns. On the other hand, states with discretionary sentencing regimes apparently can operate under less significant constraints because they lack any legislatively-imposed sentencingregulating provisions. ${ }^{191}$ Thus, functionally identical sentencing factfinding will continue to be treated differently depending on whether the state uses guided or discretionary sentencing. ${ }^{192}$

Another inter-jurisdictional absurdity exists because functionally identical findings of fact will receive divergent treatment in different states based on nothing more than the respective state courts' different assessments of the justifiability of the sentences. For example, one state's appellate court may conclude that a sixteen year sentence for bank robbery is justified even absent discharging a firearm, and therefore uphold the sentence relying on extraverdict

191. But see infra Part III.A.3 (noting that Justice Scalia's position on asapplied challenges apparently also would apply to discretionary sentencing regimes).

192. See also Priester, Canine Metaphor, supra note 9, at 222-23 (explaining this consequence prior to decisions applying Booker-Rita reasonableness review). Dissenting in Gall, Justice Alito agreed that the Court's version of the Apprendi doctrine "drew a distinction-between judicial factfinding under a guideline system and judicial factfinding under a discretionary system-that, in my judgment, cannot be defended as a matter of principle." Gall v. United States, 552 U.S. 38, 64 (2007) (Alito, J., dissenting). He added that "in both instances, facts that cause a defendant to spend more time in prison are found by judges, not juries, and therefore no distinction can be drawn as a matter of Sixth Amendment principle." Id. at 66. 
factfinding. Another state's appellate court, however, may conclude that sixteen years is unreasonable unless justified by a discharging, and therefore reverse the sentence unless discharging was established as a verdict fact. Thus, just as with intra-jurisdictional absurdities, the Court assesses the constitutionality of sentences by a roving line dependent on ad hoc appellate judgments, not any predictable or calculable maximum sentence.

It is difficult to see why the Constitution would compel a principle as flawed as the Court's current version of the Apprendi doctrine, especially when it produces divergent rulings on constitutionality in functionally identical sentencing situations. If the same finding has the same effect on the sentence, its constitutionality should not depend on ad hoc judgments of appellate courts rather than predictable or identifiable criteria.

\section{A Fixation on Factfinding: What About the Purposes of Punishment?}

Another flaw in the current version of the Apprendi doctrine derives from the Court's fixation with extraverdict factfinding at the expense of other factors also relevant to determining the appropriate sentence for a given defendant. By emphasizing so strongly the direct sentencing consequences of particular facts, the Court inadvertently may have created an incentive for trial judges to be less specific in their reasoning, and to rely more heavily on broader and more amorphous explanations such as the purposes of punishment. By doing so, sentencing judges may insulate their judgments from effective appellate review-even though their actual reasons are functionally indistinguishable from ones the Court's doctrine would invalidate.

To some extent, of course, the Court's focus on the specific sentencing effects of particular facts is understandable given the contexts in which the cases before the Court arose. In Apprendi and Harris, for example, it was clear that the additional two years of punishment challenged by the defendants were attributable to the particular extraverdict facts of hate-crime motive and firearm brandishing, respectively. Similarly, in Blakely and Booker it was possible to mathematically demonstrate the additional months of punishment attributable to the particular 
extraverdict facts that the judge had found under the applicable sentencing guidelines.

But not all sentences are based exclusively on an aggregation of specific effects of particular facts. Instead, sometimes trial judges rely on broader values such as the purposes of punishment-most frequently retribution, deterrence, incapacitation, or rehabilitation-when imposing sentence on a defendant. Is such a sentence increase also subject to challenge under Blakely-Booker analysis or BookerRita reasonableness review? To date, the Court has provided little indication about the answer.

The danger in the Court's silence is that its current doctrine's exclusive focus on factfinding creates an incentive for sentencing judges to revert to more amorphous and less precise criteria when explaining the sentences they impose. By doing so, they may insulate their judgments from effective appellate review-even though their actual reasons are functionally indistinguishable from ones the Court's doctrine would invalidate.

Many sentencing decisions based on the purposes of punishment will rely on factual findings, of course. For example, a high-end sentence imposed because the judge concludes that the defendant shows little prospect for rehabilitation, or is worthy of incapacitation, likely would be based on facts such as the defendant's history of recidivism or lack of remorse for his crime. ${ }^{193}$ Similarly, a lengthy sentence imposed for retributive reasons might be grounded in facts like the vulnerable nature of the victim or the extensive harm caused by the crime. ${ }^{194}$ To the extent these kinds of extraverdict factfinding increase a defendant's sentence, they already fall within the scope of both Blakely-Booker and Booker-Rita.

Other sentencing decisions, however, will be grounded in the purposes of punishment without relying on particular

193. For example, the Federal Sentencing Guidelines increases sentences dramatically based on the presence of prior convictions. See U.S. SENTENCING GUIDELINES MANUAL $\S 4$ A1.1 (2009); \& 5A (Sentencing Table). Similarly, a defendant who lacks remorse would be denied the downward adjustment for acceptance of responsibility. See $\S 3 \mathrm{E} 1.1$.

194. The Guidelines provide an upward adjustment for a crime against a vulnerable victim. See U.S. SENTENCING GUIDELINES MANUAL § 3A1.1 (2009). Similarly, the quantity of victim loss in a fraud case can dramatically increase the sentence. See $\$ 2$ B1.1. 
facts. The decisions may be based instead on the sentencing judge's own appraisal of the appropriate application of principles of moral philosophy and criminology to the defendant and his crime. The classic example is a lengthy sentence imposed on a defendant not for reasons of retribution or any other goal personal to the individual, but to serve the goal of general deterrence. Such a sentence is justified by the need to "send a message" that such crimes will not be tolerated. The recent sentencing of Bernard Madoff to 150 years in federal prison, for example, was heavily justified on such grounds. ${ }^{195}$ Such a sentence depends in some sense on the judge's determination that a high sentence in this case will successfully achieve the goal of general deterrence, but unlike the fact patterns in the Court's Apprendi doctrine cases, such a sentence is not based on the judge's assignment of specific sentencing value to particular facts about the crime committed or the character of the defendant himself.

Thus, the Court's emphasis on sentence increases attributable to extraverdict factfinding of specific facts inadvertently may create an incentive for trial judges to rely less on those kinds of sentencing considerations, and more heavily on generalized assessments of the purposes of punishment. After all, if a trial judge states on the record that he imposed a lengthy sentence because the defendant brandished a firearm at an elderly victim, that justification may fall within the proscriptions of Blakely-Booker and Booker-Rita. On the other hand, if the trial judge simply states on the record in the same case that he imposed a lengthy sentence based on principles of special deterrence and incapacitation - to send a message to the defendant that his crimes are serious and unacceptable-then the sentence seemingly withstands scrutiny under the Court's decisions. The sentencing judge can insulate the sentence from appellate reversal by keeping his reasons more abstract and

195. See Government's Sentencing Memorandum at 4, United States v. Madoff, No. 09-Cr.-13 (DC) (S.D.N.Y., June 26, 2009), 2009 WL 1899501 (arguing that 150 years' sentence 'forcefully would promote general deterrence"); Diana B. Henriques, Madoff, Apologizing, Is Given 150 Years, N.Y. TIMES, June 30,2009 , at A1 (noting that the sentencing judge explained that the 150 years' sentence "would be largely symbolic for Mr. Madoff, who is 71 and has a life expectancy of about 13 years" but justified it by "citing the need for retribution, deterrence and a measure of justice for the victims."). 
less precise, even though his true reasons for increasing the sentence are the same, and the sentencing consequence for the defendant is the same.

One response to this dilemma would be to subject these more amorphous sentencing considerations to scrutiny under the Apprendi doctrine. The problem with that solution, however, is obvious: implementing the purposes of punishment when imposing sentence is a paradigm example of what judges, not juries, have always done. Converting determinations about the applicability of general deterrence into elements of the jury verdict, or making findings about non-rehabilitation or incapacitation into admissions in the defendant's own plea colloquy, turns the history of sentencing practice on its head.

But if the opposite path is followed-if sentencing decisions based on the purposes of punishment rather than particular factual findings are insulated from the Apprendi doctrine - then the constitutional law of sentencing becomes even more distorted. Judges who give vague explanations grounded in moral philosophy will be affirmed, while judges who cite specific facts in the record will be reversed. The doctrine would produce the perverse result that sentencing explanations that are less arbitrary and more transparent will be more likely to be found unconstitutional. Whatever else might be true about the constitutional law of sentencing, that doctrinal outcome would be bizarre, indeed.

The implication of this conclusion is that the scope of the Court's current Apprendi doctrine reaches too far. The solution for achieving doctrinal consistency between sentences based in particular facts and sentences based in more general considerations is not to extend Apprendi to the latter, but to apply the limitations of Apprendi less widely to the former. Extraverdict reliance on the principles of punishment makes perfect sense when extraverdict reliance on particular facts is also permissible. Therefore, to avoid taking its Apprendi decisions even deeper into a doctrinal morass, the Court should roll back Blakely-Booker and Booker-Rita and remove the Constitution from many of the sentencing decisions into which the Court has incorrectly intruded it. 


\section{Protecting the Power of Judges, not Juries, Over Sentencing}

The biggest flaw in the Court's current version of the Apprendi doctrine, though, may be that the rules promulgated in the Court's decisions no longer have any meaningful connection to the purported constitutional basis of the doctrine: the Jury Trial Clause of the Sixth Amendment. Perhaps the Court's rules can be constitutionally justified on some other basis, but the Court's expansion of the power of the sentencing judge at the expense of legislative policy-making has nothing to do with the jury's role as a check against tyranny. ${ }^{196}$

Under the Apprendi doctrine, the jury plays only one role with respect to sentencing, and it is an indirect one: if the defendant does not plead guilty, then the jury must determine the presence or absence of the verdict facts that operate to constrain the outer limit of the judge's authority to impose sentence. ${ }^{197}$ Under Apprendi, the verdict facts establish the maximum available sentence defined in the statutory offense of conviction; under Blakely-Booker, the verdict facts establish the maximum available sentence under any applicable mandatory sentencing-regulating provisions; and under Justice Scalia's position on as-applied challenges, the verdict facts would establish the maximum available sentence under Booker-Rita reasonableness review. Under Harris, the minimum possible sentence may be raised through extraverdict factfinding-and even if Harris were overruled, the verdict facts still would establish only the very top and very bottom of the available sentencing range, not any further limits on the judge's authority to impose any

196. See Priester, Canine Metaphor, supra note 9, at 224-26 (explaining why the Court's Blakely-Booker expansion has nothing to do with protecting jury power at sentencing, but only the sentencing power of judges); see also Bowman, supra note 1, at 86-89 (describing data showing that Blakely-Booker has not increased jury power or increased the rate of jury trials). Professor Mandiberg argues that the Sixth Amendment jury trial right can be interpreted to require judicial discretion at sentencing by viewing it as a rejection of the civil law system, and concluding that determinate sentencing regimes like the Federal Sentencing Guidelines too closely resemble the civil law, rather than common law, system of criminal procedure. See Mandiberg, supra note 15, at 107-08, 114-18, 145-47.

197. See Priester, Canine Metaphor, supra note 9, at 224-25 (explaining why the jury's role in sentencing is indirect, not direct). 
particular sentence between them. Hence, regardless of which version of the Apprendi doctrine is applicable, the only impact that the jury has on sentencing is derivative of its power to adjudicate guilt by establishing offense elements as verdict facts. ${ }^{198}$ The jury plays no role in extraverdict factfinding, nor in calculating the specific sentence to be imposed within the outer limit authorized by the verdict facts. Yet it is precisely those aspects of sentencingextraverdict factfinding and determining the specific sentence-that Blakely-Booker and Booker-Rita were promulgated to constrain.

The framework of the tripartite analysis of a sentencing decision exposes this core reality about the Court's current version of the Apprendi doctrine. ${ }^{199}$ Undeniably, one consequence of Blakely-Booker is to require some sentencingrelated facts to be proven as first stage verdict facts rather than second stage extraverdict facts, and admittedly that nominally appears to increase jury power at the expense of judge power. But the reason the Court compelled that requirement was the third stage impact of the facts foundspecifically, the legislature's attempt to mandate particular sentencing effects for those facts. After all, the Court declared the operation of the Federal Sentencing Guidelines unconstitutional in Booker not because the Guidelines relied on extraverdict factfinding, but because they imposed mandatory increases to sentences. This must be true, in fact, because it is indisputable that, when determining a sentence increase, an extensive amount of extraverdict factfinding occurs in the post-Booker regime, and the very existence of Booker-Rita reasonableness review relies upon it and validates it. In Rita, for example, the sentencing judge engaged in extraverdict factfinding in the course of concluding that the advice of the Guidelines was sound, and a sentence below the Guidelines recommendation was not justified on the facts; in Gall, the sentencing judge engaged in extraverdict factfinding before concluding that a sentence lower than the Guidelines' advice should be imposed. ${ }^{200}$ If it

198. See id. at 225 (explaining the jury's sentencing power as derivative and secondary).

199. See supra notes 174-178 and accompanying text (describing the tripartite analytical framework).

200. See Rita v. United States, 551 U.S. 338, 344-46 (2007); Gall v. United 
were second stage extraverdict factfinding that was itself constitutionally problematic, the Court could not have developed the doctrine as it did.

Instead, what makes advisory-Guidelines-based extraverdict factfinding permissible, and mandatoryGuidelines-based extraverdict factfinding unconstitutional, is the difference between the judge having the discretion to decide the normative value of the sentencing fact and the legislature seeking to compel a specific value. The Court's opinions occasionally make the point overtly, such as when they emphasize that extraverdict factfinding is unobjectionable under the Apprendi doctrine if the judge has power to set the sentencing weight of that fact. ${ }^{201}$ Thus, it is safeguarding third stage judicial power-not expanding first stage jury power over verdict facts, or limiting the second stage judicial power over extraverdict facts-that has motivated the Court's decisions expanding the Apprendi doctrine. ${ }^{202}$

The Court's Sixth Amendment rhetoric is a charade because the Apprendi doctrine does not actually give the jury any sentencing power at all. Instead, the doctrine shields the sentencing power of judges from legislative encroachment. In

States, 552 U.S. $38,41-43$ (2007).

201. See Rita, 551 U.S. at 373 (Scalia, J., concurring). Professor Bowman makes a similar assessment:

Structured sentencing systems create the tail-wags-dog concern, not because judges in such systems necessarily identify and consider more sentence-related facts than they would in a purely discretionary system, but because the rules of structured systems assign legal weight-in the form of mandatory or preferred sentencing effects-to certain judge-found facts.

Bowman, supra note 1 , at 90 .

202. The Court's current doctrine protects the scope of judicial power over second stage extraverdict factfinding, as well. For example, one consequence of making the Guidelines advisory rather than mandatory is that sentencing judges are entitled to consider additional facts beyond those relevant under the Guidelines, as in Gall, 552 U.S. at 38 . Similarly, a sentencing judge might decide that certain facts made relevant by the Guidelines should not be considered. In one sense, then, the doctrine ensures that judges can choose which facts to consider or not consider. See Rita, 551 U.S. at 373 (Scalia, J., concurring). But the real import of this power remains at the third stage, the determination of the normative value of sentencing facts: the power to decline to consider a fact is equivalent to the power to assign it zero value, and the power to consider a fact not relevant under the Guidelines is equivalent to the power to assign it a non-zero value rather than a zero value. Thus, the second stage implications of the Court's current doctrine implicate the judicial power of policy nullification, discussed in detail below. See infra Part III.B. 
essence, the doctrine concedes that legislatures may limit the power of judges through the terms of the offense-defining statutes that authorize punishments, but imposes significant restrictions on the use of sentencing-regulating provisions with extraverdict factfinding to limit the power of judges to determine a particular defendant's sentence. ${ }^{203}$ The Court's rhetoric claims that the Apprendi doctrine protects jury power from legislative diminution, but its test for assessing whether a constitutional violation has occurred is whether the challenged provision has diminished judicial power. ${ }^{204}$

Thus, the true consequence of the Court's decisions expanding the Apprendi doctrine is to constitutionalize a high degree of judicial power over sentencing at the expense of legislatures. Those decisions do not increase the power of the jury over the nuances and details of sentencing determinations-those intricacies remain subject to judgefound extraverdict factfinding even under the most expansive language in the Court's opinions. Instead, the Court's decisions ensure that those details remain the exclusive domain of judges, unconstrained by the preferences of the legislature. Legislatures may set the available penalties for offenses using verdict facts, but once that scope of punishment is established, the Court insists that the power to consider sentencing facts and assess their normative worth must rest with judges.

And the constitutional doctrine may be even more restrictive than that, if the full Court follows through in adopting Justice Scalia's position regarding as-applied challenges. If he is correct in his constitutional analysis, then the power to make the determinative third stage decisions of the normative value of sentencing facts is constitutionally vested not just in judges in general, but in trial judges in particular. Under Justice Scalia's analysis, a violation of the

203. See Priester, Canine Metaphor, supra note 9, at 214-21, 234, 240, 25259.

204. See id. at 261.

The Apprendi line of cases sounds in populism, defending representative, responsive juries against the interference of unelected sentencing judges. Now, however, the tables are turned, and the Court is rejecting democratic sentencing laws to preserve the independence and freedom of those very same unelected sentencing judges. The turnabout is ironic.

Bibas \& Klein, supra note 15, at 781. 
Apprendi doctrine occurs whenever an extraverdict fact was necessary to justify the increased sentence imposed-and this principle applies not only to offense-defining statutes or mandatory sentencing-regulating provisions, but also to the operation of appellate review. ${ }^{205}$ If a lengthy sentence would constitute an abuse of discretion under Booker-Rita reasonableness review but for the presence of certain additional facts, then those facts are necessary to the sentence and must be proven as verdict facts rather than extraverdict facts.

The ramifications of Justice Scalia's analysis are profound. If he is correct, then abuse of discretion review of sentencing decisions is not merely a statutory interpretation solution to the merits holding of Booker, but is in fact constitutionally mandated in all cases. Under any more stringent standard of appellate review, far more facts would become necessary to justify particular sentences, producing far more as-applied violations of the Apprendi doctrine. Consider, for example, a sentencing regime that provides for clearly erroneous review of the trial judge's findings of sentencing facts but de novo review of the normative value of those facts and the ultimate length of sentence imposed. In such a regime, numerous sentences would be subject to reversal simply because the appellate court weighed the value of the facts differently ${ }^{206}$ _including cases in which the appellate court would order a higher sentence than the lower court imposed based on a reweighing of the facts. In many cases in such a regime, the appellate court would approve the sentence, or order a higher sentence, based on its own assessment of the value of the facts found at sentencing. Yet this is exactly what Justice Scalia's constitutional analysis

205. See supra Part II.A.3; see also Bibas \& Klein, supra note 15, at 782-84 (criticizing Justice Scalia's position as "too extreme"); Bowman, supra note 1, at 62 (arguing that "the central flaw in Scalia's Blakely view ... is that it amounts to a declaration that, where judicial sentencing discretion exists, the exercise of that discretion cannot be subjected to the rule of law."); $i d$. at 70 ("This is the architect of the Blakely formula declaring that the Constitution prohibits appellate review of the substance of trial judges' discretionary sentencing choices.").

206. In Gall, the Court emphasized that such a reweighing of the facts is not permissible under Booker-Rita reasonableness review. See Gall v. United States, 552 U.S. 38, 51 (2007) ("The fact that the appellate court might reasonably have concluded that a different sentence was appropriate is insufficient to justify reversal of the district court."). 
forbids: making the finding of extraverdict facts mandatory to the validity of a sentence. Just as abuse of discretion review is required to ensure that the Guidelines carry only advisory weight in a judge's sentencing decision, so too it would also be required to ensure that appellate court decision-making does not have the effect of causing extraverdict facts to become necessary to support particular sentences. ${ }^{207}$ Thus, if the Court adopts Justice Scalia's constitutional analysis on asapplied challenges, it will be constitutionalizing not just judicial power in general to make the determinative decisions about particular sentences, but specifically trial judge power over those decisions.

All of this suggests that, while the Court clearly is undertaking to use constitutional law to solidify judicial power over sentencing against legislative encroachment, it also may be simultaneously constitutionalizing a particular vision of sentencing: the primacy of the interest in the individualized sentencing of each particular defendant over the interest in systemic uniformity in the sentencing of all defendants. ${ }^{208}$ In Gall, for example, the Court explained that the sentencing judge "must make an individualized assessment based on the facts presented" and must " consider every convicted person as an individual and every case as a unique study in the human failings" that lead to crime. ${ }^{209}$ In Kimbrough and Spears, the Court authorized sentencing judges to pursue their own views on appropriate cocaine sentencing policy, even though that would produce widely

207. Ironically, this doctrinal position would have the effect of mitigating some of the absurdities resulting from the Court's formalism. See supra Part III.A.1. Currently, there is a wide gulf between the constitutional restrictions on sentencing regimes based on mandatory or advisory guidelines and similar laws on the one hand, and regimes with judicial discretion unregulated by legislative sentencing-regulating provisions on the other. This discrepancy has the effect of creating divergences in the constitutionality of functionally identical sentencing findings as between the two systems. See supra Part III.A.1. If the Court further expanded its doctrine to encompass Justice Scalia's position, however, then the same requirement for deferential appellate review would apply in all systems, and substantial reservations of trial court power over sentencing would be required in all systems. Although differentials would remain with respect to Blakely-Booker issues, see supra Part III.A.1, it would eliminate any differential in the constitutionality of as-applied challenges to the operation of appellate review.

208. See Priester, Canine Metaphor, supra note 9, at 260-69.

209. Gall, 552 U.S. at 50, 52 (quoting Koon v. United States, 518 U.S. 81, 113 (1996)). 
varying crack-to-powder ratios among different judges. The Court has not, however, placed similar emphasis on the notion that sentencing judges should take account of considerations of systemic uniformity or comparable treatment of similar cases, but has only mentioned those considerations tangentially. ${ }^{210}$ Likewise, if legislatures want to constrain sentencing with considerations of systemic uniformity, they can only do so in a binding manner using verdict facts. ${ }^{211}$ Although the Court has not overtly declared that the Constitution mandates the primacy of individualized sentencing over systemic uniformity, it seems to be a clear implication of the Court's reasoning in its decisions expanding the Apprendi doctrine.

The Court's use of constitutional law to expand judicial power over sentencing is problematic for several significant reasons. For one, the constitutional structure of criminal procedure has never previously been construed to require exclusive judicial power over determinations of the length of a defendant's sentence. ${ }^{212}$ For another, the Court's rule imposes constraints not only on Congress' power to enact sentencing-regulating provisions for federal offenses, but also on each of the fifty state legislatures. The Court thereby has eliminated much of the opportunity for states to serve their long-valued salutary role as laboratories of experimentation

210. For example, in Gall the Court maintained that the procedural step of simply considering the advice of the Guidelines as part of the overall sentencing determination in and of itself "necessarily gave significant weight and consideration to the need to avoid unwarranted disparities." Gall, 552 U.S. at 54. Similarly, although the Court in Kimbrough recognized that avoiding unwarranted disparities is a factor which must be considered under $\S$ 3553(a)(6), see Kimbrough v. United States, 552 U.S. 85, 107-08 (2007), the Court declared that "some departures from uniformity were a necessary cost of the remedy we adopted" in Booker, and added that while "district courts must take account of sentencing practices in other courts," those "disparities must be weighed against . . . any unwarranted disparity created by the crack/powder ratio itself." Id. at 108. Dissenting in Gall, Justice Alito commented that the majority's analysis would "impose few real restraints on sentencing judges" and consequently "sentencing disparities will gradually increase." Gall, 552 U.S. at 63-64 (Alito, J., dissenting).

211. Options for limiting judicial sentencing authority using verdict facts might include statutory mandatory minimum sentences in offense-defining statutes, narrower punishment ranges in offense-defining statutes, or a highly detailed criminal code similar to "Blakely-ized" Guidelines. See Priester, Structuring Sentencing, supra note 10, at 921-23, 929-34; Priester, Canine Metaphor, supra note 9, at 247-52.

212. See Priester, Structuring Sentencing, supra note 10, at 891-96, 928-34. 
for public policy. ${ }^{213}$ For example, the Court has precluded states from experimenting with sentencing regimes such as discretionary sentencing with de novo review, or presumptive sentences with deferential review. ${ }^{214}$ If the constitutional arguments in favor of the Court's rule were stronger, perhaps its claims would have more force. Instead, the Court's decisions seem less like persuasive constitutional analysis and more like a self-interested institutional power-grab. ${ }^{215}$

\section{B. Policy Nullification: The Ultimate Judicial Power-Grab}

In criminal trials, jury nullification has long-standing significance. ${ }^{216}$ Even though it is controversial-it does, after all, allow jurors to reject the judge's instructions and acquit clearly guilty defendants against the weight of the evidencewe retain jury nullification in our criminal justice system because it preserves an anti-tyranny mechanism we value more than the prevention of the occasional imprudent or undeserved acquittal. ${ }^{217}$ As the Court has emphasized from the beginning of this line of cases, the Apprendi doctrine's "animating principle is the preservation of the jury's historic role as a bulwark between the State and the accused at the trial for an alleged offense." ${ }^{218}$ When the criminal law or its

213. See, e.g., Berman \& Bibas, supra note 17 , at 38-39, 40-42, 62-72.

214. See, e.g., id. at 63-65, 70-71.

215. See Priester, Canine Metaphor, supra note 9, at 260-66 (arguing that Blakely-Booker constitutes an illegitimate institutional power-grab).

216. See, e.g., Andrew D. Leipold, Rethinking Jury Nullification, 82 VA. L. REv. 253 (1996); Jack B. Weinstein, Considering Jury "Nullification": When May and Should a Jury Reject the Law to Do Justice, 30 AM. CRIM. L. REV. 239 (1993).

The critical feature of nullification is the jurors' decision to acquit even though they believe the defendant committed acts that met the statutory definition of the crime. Thus, for example, a jury might agree that the defendant knowingly possessed a small amount of illegal drugs, but nevertheless acquit because it believes sending the defendant to jail would be too harsh. By acquitting, the jury has 'nullified' the drug possession law, at least for that case.

Leipold, supra, at 253-54 n.1.

217. See, e.g., Morris B. Hoffman, The Case for Jury Sentencing, 52 DukE L.J. 951, 959-63, 992-99 (2003); Rachel Barkow, Separation of Powers and the Criminal Law, 58 STAN. L. REv. 989, 1012-17 (2006). For mention of several controversial acquittals in the early 1990s, see Leipold, supra note 216, at 25455 \& nn.2-5 (discussing Marion Barry, Jack Kevorkian, and Oliver North). Another example often mentioned as jury nullification is, of course, the acquittal of O.J. Simpson in 1995.

218. Oregon v. Ice, 129 S. Ct. 711, 717 (2009) (citing Apprendi v. New Jersey, 
enforcement is unjust, the jury can prevent an injustice.

In criminal sentencing, on the other hand, the power of the judge to actively thwart the enforcement of the law is far more constrained. When the legislature has enacted an offense, the prosecution has charged it, and the jury has convicted, we ordinarily expect the judge to impose a fair, reasoned sentence upon the defendant. ${ }^{219}$ Sometimes a higher end or lower end sentence is justified on the facts of the case, such as when the government persuades the judge that the offender is particularly blameworthy or the defense persuades the judge that the offender is worthy of mercy. ${ }^{220}$ Other times the judge may more overtly disagree with the actions of another actor, such as when a sentencing judge believes the prosecution has "over-charged" the case relative to the defendant's actual culpability and consequently imposes a low-end sentence over the government's objection. ${ }^{221}$ When it comes to legislative enactments, however, we typically describe a sentencing judge as engaged in the enterprise of applying the law to pass judgment on the offender, and not using the offender's case to pass judgment on the law. ${ }^{222}$

Yet in recent cases, the Court has apparently staked a claim to judicial constitutional power to engage in exactly this kind of "policy nullification," seemingly granting to federal judges unbridled authority to reject the criminal justice policy decisions made by Congress in favor of their own policy preferences. And this power would seem to rest not in federal judges institutionally, acting in the aggregate, but-due to the operation of Booker-Rita reasonableness review-in each

530 U.S. 466, 477 (2000)); see also Jones v. United States, 526 U.S. 227, 244-48 (1999) (citing, among others, 4 WILLIAM BLACKSTONE, COMMENTARIES).

219. See Priester, Structuring Sentencing, supra note 10, at 891-95 (describing the constitutional structure of criminal procedure).

220. See supra note 195 and accompanying text (discussing the 150 year sentence imposed on Bernard Madoff).

221. See Stephanos Bibas, Pleas' Progress, 102 Mich. L. REv. 1024, 1039 (2004) (noting that, under pre-Booker Guidelines, "[p]rosecutors can overcharge to gain leverage for harsh sentences, and judges have little power to check prosecutorial harshness. If judges try to cut sweet deals unilaterally, say by departing from the Guidelines, they face appellate reversal.").

222. Historically, judges did have several tools for mitigating harsh sentences mandated by legislatures. See Mandiberg, supra note 15, at 118-23 (discussing technical common law procedural rules, benefit of clergy, suspended imposition of sentences, and recommendation for executive pardon). 
individual federal judge in each particular case. Given the narrow, fact-bound nature of the decisions to date with policy nullification ramifications, it is possible the Court will not follow its rhetoric and rationales through to their logical conclusion. But given the trajectory of the Apprendi doctrine so far, and the Court's willingness to use those cases to grab power for the judiciary, ${ }^{223}$ it is also entirely possible that the Court will use a future case to solidify definitive judicial authority to engage in policy nullification at sentencing.

\section{What Counts as Policy Nullification? The Case of Letter versus Spirit}

Before examining the extent to which the Court may be constitutionalizing a judicial power to engage in policy nullification at sentencing, it is necessary to define what kind of judicial actions qualify as policy nullification. One option would be to define the phrase narrowly, by close analogy to jury nullification: that is, a judge engages in policy nullification only when the judge rejects a specific legislative policy expressly enacted in a sentencing-regulating statute. Under this definition most sentencing decisions would not constitute policy nullification, because such specific legislative policy choices tend to be rare. Another option would be to define policy nullification more broadly: a judge engages in policy nullification whenever the judge's sentencing decision is inconsistent with implicit legislative policy choices. Under this definition, by contrast, many more sentencing determinations would constitute policy nullification, because the scope of the field of issues implicitly addressed by the legislature is far wider. Thus, the former definition emphasizes the letter of the law, while the latter focuses on the spirit.

The Court's decisions to date have involved technical compliance with the letter of the statutes enacted by Congress. In Gall, the district judge imposed a lower sentence based in part on the defendant's college-student age, his emotional immaturity at the time of his offense, and his strong family ties at the time of sentencing. ${ }^{224}$ Under the

223. See Priester, Canine Metaphor, supra note 9, at 261-62 (discussing the Court's decisions as a power-grab).

224. See Gall v. United States, 552 U.S. 38, 43-45, 57-58 (2007). 
Guidelines, such considerations are prohibited when calculating a sentence; ${ }^{225}$ but that prohibition is only a determination of the Sentencing Commission, not a statutory policy enacted by Congress. ${ }^{226}$ Consequently, when the Court upheld the sentence as reasonable under Booker-Rita, it ratified the district judge's rejection of the Commission's advice, not a repudiation of a specific sentencing policy adopted either expressly or impliedly by Congress. ${ }^{227}$ The same was nominally true in Kimbrough, where the district judge sentenced Kimbrough to the statutorily-mandated minimum sentence required for the quantities of crack and powder cocaine to which he had admitted in his guilty plea, thereby complying with the 100:1 ratio as codified in the letter of the statute enacted by Congress. ${ }^{228}$ The judge refused to impose the longer sentence recommended by the Guidelines, however, based on the judge's rejection-as bad policy—of the Commission's decision to incorporate the 100:1 ratio across the full range of cocaine sentences. ${ }^{22}$ The Court upheld the sentence, concluding that the district judge was entitled to reject the advice of the Guidelines based on policy disagreement with the ratio. ${ }^{230}$ As a technical matter, then, both cases only involved the Commission's sentencing advice, not a specific sentencing policy expressly enacted by

225. See U.S. SENTENCING GUIDELINES MANUAL $\$ \S 5$ H1.1 \& 1.6 (2009).

226. In the statutes creating the Sentencing Commission and its authority to promulgate the Guidelines, Congress instructed the Commission "to establish uniform national sentencing policies" regarding age and family ties, as well as a number of other disputed sentencing considerations. See Gall, 552 U.S. at 6970 (Alito, J., dissenting) (discussing 28 U.S.C. § 994(d) and the Commission's actions pursuant to it). It was therefore the Commission, not Congress, that adopted the Guidelines rule that age and family ties were not ordinarily relevant to sentencing. See id.; see also U.S. SENTENCING GUIDELINES MANUAL $\S \S 5 \mathrm{H} 1.1 \& 1.6$.

227. See Gall, 552 U.S. at 58 ("[I]t was not unreasonable for the District Court to view Gall's immaturity at the time of the offense as a mitigating factor, and his later behavior as a sign that he had matured ...."). Cf. id. at 69 (Alito, J., dissenting) (stating that the district judge's consideration of Gall's age and immaturity "amounted to a direct rejection of the Sentencing Commission's authority to decide the most basic issues of sentencing policy.").

228. See Kimbrough v. United States, 552 U.S. 85, 92-93 \& n.3 (2007) (explaining defendant's guilty plea admissions and sentenced imposed); id. at 102-03 (noting that text of statute creates only mandatory minimums and "says nothing about the appropriate sentences within these brackets").

229. See id. at 93, 110-11 (describing district court's rejection of Guidelines sentence under $\S 3553(\mathrm{a})$ analysis).

230. See id. at 100-10. 
Congress.

Unlike Gall, however, where Congress had taken no position on the issue, in Kimbrough the courts' ignoring of the ratio in calculating the sentence arguably rejected a policy impliedly adopted in the offense-defining statute: that crack sentences should be considerably more severe than powder sentences. The Government advanced a stronger version of this argument in Kimbrough, urging the Court to conclude that the three-tiered $\S 841$ offense "implicitly requires" the identical 100:1 ratio to be applied in sentences pursuant to the Guidelines and $\S 3553(\mathrm{a})$, as well. ${ }^{231}$ The Court disposed of this argument by reasoning that the text of the three-tiered offense statute "says nothing about the appropriate sentences within these brackets, and we decline to read any implicit directive into that congressional silence." ${ }^{232}$ This is, of course, a non-sequitur: every argument by implication necessarily arises from an issue not expressly addressed in a text. The question the Court needed to address was whether the inference about sentencing policy the Government sought to draw from the offense definition was a good one-that is, whether the inference was justified in the full interpretive context. The Court mentioned several relevant considerations on that score, such as prior precedent and the history of Commission proposals to alter the ratio in the Guidelines, but specifically addressed them only in the context of rejecting the Government's argument for the identical 100:1 ratio. ${ }^{233}$

The Court did not address, however, the possibility that the $\S 841$ offense might carry a weaker but still meaningful implication about sentencing: specifically, that crack sentences should be considerably more severe than powder sentences. Even if Congress did not necessarily intend for the

231. See id. at 102 (internal quotations omitted).

232. Id. at 103.

233. See id. at 103-06. The Court drew an analogy to its prior cases involving the conflicting statutory tiers and Guidelines provisions for determining the quantity of LSD to be used in determining the sentence. See $i d$. at 103-05 (discussing Neal v. United States, 516 U.S. 284 (1996) and Chapman v. United States, 500 U.S. 453 (1991)). The Court also noted that Congress had rejected a Commission proposal for a 1:1 Guidelines ratio in 1995, but had allowed a 2007 amendment for a reduced Guidelines ratio (varying from 25:1 to $80: 1$ depending on quantity) to take effect. See Kimbrough, 552 U.S. at $105-06$. 
exact ratio from the offense statute to be used reflexively in the sentencing calculation in each particular case, surely the fact that the offense differentiates the severity of crack and powder offenses by two orders of magnitude implies at the very least that it is inappropriate for a sentencing judge to impose sentence based on no differentiation between them. Perhaps the 20:1 ratio adopted by the district court in Spears would be consistent with a weaker implication of the offense statute, or perhaps not. But even if that were the case, the Court did not revisit its terse analysis in Kimbrough, either. ${ }^{234}$ Consequently, in Kimbrough and Spears the Court upheld the district courts' policy rejection of the 100:1 ratio without giving adequate consideration to the sentencing policies embodied in the spirit, if not the letter, of the statutes adopted by Congress.

The Court's rulings in Gall and Kimbrough, therefore, seem to recognize judicial authority to engage in policy nullification in the broader definitional sense. That is, so long as the sentencing judge has complied with any applicable express statutory directives of Congress, the Court maintains that the judge is free to follow whatever sentencing policies the judge sees fit. But is this right? Is it a fair statement of judicial power at sentencing? Put another way, is the Court actually correct in Kimbrough to conclude that complete repudiation at the sentencing stage of the crack-to-powder ratio required to be enforced at the conviction stage is legitimate judicial action? In its opinions, the Court seems simply to assume that this form of policy nullification is legitimate, without seriously addressing the consequences or ramifications of recognizing such judicial power.

If the Court does mean to gives its imprimatur to policy nullification in the broader sense, and sentencing judges are not at all constrained by the spirit of the criminal law but only by its letter, then the potentially significant consequences are not difficult to foresee. What, then, is to prevent one district judge from concluding that criminalization of gun offenses shows insufficient respect to the fundamental importance of gun rights to American society, and from consequently imposing low-end sentences on every gun conviction in his courtroom-while another district

234. See Spears v. United States, 129 S. Ct. 840, 842-44 (2009) (per curiam). 
judge concludes that illegal use of firearms in crime undermines the legitimate gun rights of law-abiding citizens in the face of clamor for gun control, justifying high-end sentences for every gun crime? Those were the very kind of divergent sentencing policy decisions that led to the creation of the Guidelines in the first place. ${ }^{235}$ Yet if policy nullification is legitimate at the level of each sentencing judge, then the proliferation of such divergences is inevitable.

Similarly, if policy nullification is permissible, then nothing prevents a district judge from concluding that marijuana criminalization is bad policy and consequently imposing the lowest available sentence in every marijuana case. As in Kimbrough, such a judge clearly would be complying with the letter of the law-and just as clearly violating its spirit. After all, it is one thing to impose a lowerthan-typical sentence when the judge believes the particular facts of the given case are far removed from typical. ${ }^{236}$ Such a sentence is simply a good faith application of the law to the facts - even if the judge might be "wrong" that the facts of the case actually are atypical. But it is something else entirely to impose a lower-than-typical sentence in every case of a certain type because the judge thinks the legislature made bad policy. That is not a good faith application of the law; it is a refusal to apply the law simply because the judge believes the law should be different. Does that not constitute an iconic instance of the judge acting as super-legislature, which judges are generally thought to be institutionally obligated to avoid? ${ }^{237}$ The Court in Gall and Kimbrough, however,

235. See Gall v. United States, 552 U.S. 38, 69-70 (2007) (Alito, J., dissenting) (discussing reasons why Congress directed the Commission to standardize judicial consideration of factors, like age and family ties, that received divergent consideration by different judges).

236. See Kimbrough, 552 U.S. at 109 (explaining that "a district court's decision to vary from the advisory Guidelines may attract greatest respect when the sentencing judge finds a particular case outside the heartland to which the Commission intends individual Guidelines to apply.") (internal quotations omitted); see also Gall, 552 U.S. at 43-45, 59-60 (noting that a sentence of probation was atypical, but affirming the sentence as not an abuse of discretion on the facts under Booker-Rita reasonableness review).

237. See, e.g., Ewing v. California, 538 U.S. 11, 27-28 (2003).

To be sure, California's three strikes law has sparked controversy. Critics have doubted the law's wisdom, cost-efficiency, and effectiveness in reaching its goals. This criticism is appropriately directed at the legislature, which has primary responsibility for making the difficult policy choices that underlie any criminal sentencing 
apparently authorizes sentencing judges in criminal sentencing to do exactly that.

Perhaps the Court believes that judges' consideration of the $\S 3553(\mathrm{a})$ factors will prevent many instances of policy nullification, but that possible constraint would appear to be foreclosed by the Court's own analysis in Kimbrough. In upholding the district court's refusal to apply the crack-topowder ratio in calculating the sentence, the Court expressly stated that the sentencing judge was entitled to replace the Commission's assessment of the $\S 3553$ (a) factors with its own assessment "even in a mine-run case." 238 The Court reaffirmed this conclusion in Spears, emphasizing that "district courts are entitled to reject and vary categorically from the crack-cocaine Guidelines based on a policy disagreement with those Guidelines." 239 Thus, so long as the sentence was in technical compliance with congressional directives by following the statutory mandatory minimum sentence, the Court believed that the judge was authorized to conclude that applying the ratio was bad sentencing policy under $\S 3553(\mathrm{a})$. Perhaps the Court's interpretation of $\S$ 3553(a) is correct, and the statute does contemplate that sentencing judges will in some cases engage in technical compliance plus policy nullification, rather than a good faith effort to follow the spirit as well as the letter of the law. But

scheme. We do not sit as a 'superlegislature' to second-guess these policy choices.

Id. (internal citations omitted).

238. Kimbrough v. United States, 552 U.S. 85, 109 (noting that "closer review may be in order when the sentencing judge varies from the Guidelines based solely on the judge's view that the Guidelines range 'fails properly to reflect $\S$ 3553(a) considerations' even in a mine-run case.") (quoting Rita v. United States, 551 U.S. 338, 351 (2007)); id. at 110 (explaining that "it would not be an abuse of discretion for a district court to conclude when sentencing a particular defendant that the crack/powder disparity yields a sentence greater than necessary to achieve $\S 3553$ (a)'s purposes, even in a mine-run case."). In Spears, the district judge substituted a ratio of 20:1 instead of a ratio of 100:1. See Spears, 129 S. Ct. at 842.

239. Spears, 129 S. Ct. at 843-44; see also id. at 843 ("That was indeed the point of Kimbrough: a recognition of district courts' authority to vary from the crack cocaine Guidelines based on policy disagreement with them, and not simply based on an individualized determination that they yield an excessive sentence in a particular case."). As in Kimbrough, the defendant in Spears received the statutory mandatory minimum sentence (240 months) for the quantities of crack and powder cocaine established as verdict facts, a sentence that fell well below the Guidelines sentence using the 100:1 ratio (324-405 months). See id. at 841-42. 
that interpretation requires reading $\S 3553(\mathrm{a})$ in isolation, as a mere regulation of sentencing authority divorced from any connection to the substantive offense upon which sentence is being imposed-and it is certainly not clear that Congress would have intended $\S 3553(\mathrm{a})$ to encompass sentencing policy nullification. The Court likely should have undertaken briefing and argument on the question, rather than simply assuming that its construction of $\S 3553(a)$ is correct.

Another possibility is that the Kimbrough Court believes its language authorizing policy nullification will not be elaborated and extended by the lower courts because it is limited to the particular context of the highly controversial crack-to-powder ratio. At first blush, this might be plausible: the Spears opinion, for example, describes the holding of Kimbrough only in terms of the crack-to-powder ratio. ${ }^{240}$ Likewise, the Kimbrough opinion contains an extensive discussion of the many criticisms of the ratio and efforts to change it ${ }^{241}$ including emphasizing that the Guidelines ratio was adopted merely by transposing the offense-statute's ratio rather than a separate consideration of sound sentencing policy. ${ }^{242}$ This might suggest, then, that district judges are authorized to engage in policy nullification only for highly contestable or empirically dubious policy decisions, but not in more mundane situations. ${ }^{243}$ But that window may be nearly impossible to close: after all, surely it would not be difficult for the marijuana-nullifying judge to marshal the full range of well known pro-legalization arguments to support an argument that the application of the $\S 3553(\mathrm{a})$ factors points toward a rejection of congressional policy even in the minerun case. ${ }^{244}$ For example, the empirically and normatively

240. See, e.g., id. at 843 ("Kimbrough thus holds that with respect to the crack cocaine Guidelines, a categorical disagreement with and variance from the Guidelines is not suspect.") (emphasis added).

241. See Kimbrough, 552 U.S. at 94-100.

242. See id. at 96-97; id. at 109 ("The crack cocaine Guidelines, however, present no occasion for elaborative discussion . . . because those Guidelines do not exemplify the Commission's exercise of its characteristic institutional role.").

243. But cf. Adelman \& Dietrich, supra note 15 (discussing four additional Guidelines provisions with which district judges might also find significant policy flaws); Bibas \& Klein, supra note 15, at 775-76 (concluding that Kimbrough's reasoning is not limited to the crack-to-powder Guideline); Bowman, supra note 1, at 74-75, 80 (concluding that implications of Kimbrough for other Guidelines are unclear).

244. See, e.g., Eric Blumenson \& Eva Nilsen, Liberty Lost: The Moral Case for 
based arguments that marijuana causes less, or at least no worse, social harm than alcohol consumption or tobacco cigarette smoking would be relevant to sentencing purposes such as retribution and deterrence, as well as to avoiding unwarranted disparities. ${ }^{245}$ These are, of course, the very same kinds of arguments marshaled in favor of abolishing the crack-to-powder ratio for cocaine offenses. ${ }^{246}$

It seems likely, though, that the Court considers policy nullification as manifested in Gall and Kimbrough to be an integral part of the sentencing discretion vested in district judges by Booker-Rita reasonableness review. Consequently, addressing the legitimacy of policy nullification in the broad sense-when sentencing judges comply with the letter of the law but, at least arguably, not its spirit-is a necessary discussion.

Yet even beyond that discussion is a deeper set of ramifications in the Court's policy nullification decisions. If the principles of the Court's holdings in Blakely-Booker are followed to their logical conclusions - especially if the doctrine is expanded to include Justice Scalia's position regarding asapplied challenges-then the Court will sanction not only the broad form of policy nullification, but the narrow form, as well. In other words, the Court may very well be poised to rule unconstitutional a legislative attempt to use the letter of the law to statutorily prevent policy nullification.

\section{The Constitutional Implications of Policy Nullification Under Apprendi Doctrine}

Whatever the bounds of judges' authority to pursue their own determinations of sentencing policy when the legislature has spoken only impliedly, if at all, on the matter in question, judicial policy nullification would rise to another degree entirely if judges also had the power to ignore express declarations of legislative sentencing policy. Although the Court has not yet overtly suggested that the Apprendi doctrine compels the recognition of that power, the rhetoric and rationales of the Court's decisions point strongly in that direction. It would not be surprising, then, to see the Court in

Marijuana Law Reform, 85 IND. L.J. 279, 283-89 (2010).

245. See 18 U.S.C. § 3553(a)(2) \& (6) (2006).

246. See Kimbrough v. United States, 552 U.S. 85, 93, 97-99, 108, 109-11. 
a future case strike down as unconstitutional a statute which seeks to enforce a specific legislative policy upon sentencing judges.

How could such a dispute over specific sentencing policy arise? The facts of Gall provide a good example, where the problematic factors of the defendant's age and family ties are in play. Prior to the Guidelines, there was little uniformity in how sentencing judges considered these factors. ${ }^{247}$ Some judges might consider young age to be a mitigating factor due to immaturity and bad judgment, while others might consider an older age to be an aggravating factor because a more mature grown-up should have known better. ${ }^{248}$ Similarly, some judges treated the defendant's family ties as a mitigating factor due to the negative collateral consequences of the defendant's incarceration on his family, while other judges viewed those consequences as grounds to punish the defendant more severely for selfishly making his family suffer for his crimes. ${ }^{249}$ The Guidelines sought to achieve systemic uniformity on these factors by deeming both of them "not ordinarily relevant" to calculating the defendant's sentence. ${ }^{250}$ After Booker, those Guidelines proscriptions are now advisory and sentencing judges are entitled, as in Gall, to once again take those factors into account in determining a sentence.

But what if Congress still values systemic uniformity on these factors? The Guidelines may be advisory, but statutes are not. What would be the constitutional implications if Congress sought to expressly legislate specific statutory sentencing policies regarding the consideration of age and family ties? The Apprendi doctrine already imposes constitutional constraints on certain types of legislative mandates, but the existing doctrine is silent on others.

For example, imagine Congress concluded that the "you should have known better" perspective on age and family ties

247. See Gall v. United States, 552 U.S. 38, 70 (2007) (Alito, J., dissenting).

248. See Bibas et al., supra note 15 , at 1388-89 (noting that some judges considered youthful age to be a mitigating factor, while others considered it an aggravating factor).

249. See Gall, 552 U.S. at 70 (Alito, J., dissenting) (noting that some judges considered family ties as mitigating circumstance due to family's ability to assist offender in rehabilitation to avoid re-offending).

250. See U.S. SENTENCING GUIDELINES MANUAL §§ 5H1.1 \& 1.6 (2009); see also Gall, 552 U.S. at 69-70 (Alito, J., dissenting) (explaining the origin of these Guidelines provisions). 
was the better sentencing policy, and sought to impose that policy uniformly for all federal sentences. If Congress sought to implement it with mandatory sentence increases-whether by a fixed number (such as six additional months) or a percentage (such as an additional twenty percent) compared to the otherwise applicable sentence-based on a finding of the defendant's age or family ties, then those facts would have to be established as verdict facts to avoid unconstitutionality under Apprendi and Blakely-Booker. ${ }^{251}$ Similarly, if Harris is overruled, then a mandatory minimum provision achieving the same objective also would require proof as a verdict fact. ${ }^{252}$

But what if Congress simply wished to ratify and codifyand make mandatory rather than advisory-the policy selected by the Commission in the Guidelines, that age and family ties are ordinarily not to be considered in determining a sentence? To make its intention clear, and to avoid any interpretive debate of the kind seen in Kimbrough, Congress might pass a statute expressly declaring: "When determining a sentence pursuant to $\S 3553(\mathrm{a})$, the defendant's age and family ties shall not ordinarily be relevant." Is such a statute constitutional?

The prohibition would pass muster under the terms of the Apprendi doctrine cases to date, of course. Most obviously, the statute does not involve an affirmative finding of fact, so by definition it cannot produce a sentencing result in which extraverdict factfinding increased a maximum sentence. Even Justice Scalia's concern about as-applied challenges to Booker-Rita reasonableness appellate review is limited to situations in which additional extraverdict facts are used to justify longer sentences. This statute, then, would not contravene the scope of the current Apprendi doctrine.

Yet the statute surely seems to raise Apprendi doctrine implications, because it presents the converse situation of those decisions. In many cases, the statutory prohibition would operate to mandate a longer sentence than that would otherwise be imposed by the judge. Just as the extraverdict

251. Proof as a verdict fact is required if the fact will be used to increase a statutory maximum sentence or a binding maximum sentence from a sentencing-regulating provision. See supra Part II.A.1-2 (discussing Apprendi and Blakely-Booker).

252. See supra Part II.A.4 (discussing Harris). 
findings in Blakely and Booker mandated longer sentences than would have been imposed based on the verdict facts, the statutory prohibition on considering age and family ties would mandate a longer sentence in Gall than would have been imposed if the judge were permitted to consider those facts.

Why, then, should the Court distinguish for Apprendi doctrine purposes between a statute that mandates sentencing increases and a statute that prohibits sentencing decreases? The net effect is the same: in both Blakely-Booker on the one hand, and Gall on the other, the operation of the sentencing provision takes away the judge's authority to impose a shorter sentence on the defendant.

Consistent with its rationale in Apprendi doctrine decisions, therefore, the Court might very well declare unconstitutional such a statutory prohibition. The doctrinal principles from Apprendi and Blakely-Booker constrain legislatures into using verdict facts to determine or increase the top end of the sentence that may be imposed-and, if Harris is overruled, the bottom end as well. The application of Booker-Rita reasonableness review, ensuring that the Apprendi doctrine is not violated when sentences are imposed, has furthered emphasized that the Guidelines must be truly advisory to avoid unconstitutionality. It is hardly a doctrinal shift to synthesize these cases into a rule providing that the legislature may limit judicial sentencing power through mandatory limits imposed by verdict facts, but within those limits sentencing judges retain full discretion to impose any available sentence-and correspondingly, any legislative attempt to constrain that sentencing discretion, either by a mandatory provision relying on specific extraverdict factfinding or by a mandatory provision prohibiting specific extraverdict factfinding, is an unconstitutional interference with judicial power.

Such an expansion of the Apprendi doctrine to encompass policy nullification of express statutory policies is not a foregone conclusion, however. One core rationale of the Apprendi doctrine has been that extraverdict sentence enhancements are unconstitutional because they deprive the defendant of a guaranteed lower sentence; that is, absent the application of the extraverdict enhancement, the defendant 
would have been "entitled" to a lower sentence. ${ }^{253}$ The application of a statutory prohibition on considering age or family ties, by contrast, only deprives the defendant of the opportunity for a lower sentence, because there is no certainty that the judge would have imposed a lower sentence in the case if consideration of those factors had been permissible. Accordingly, the Court might distinguish mandatory enhancements from mandatory prohibitions, and find the latter to be constitutional.

In addition, so long as Harris remains good law the Court may be reluctant to expand the Apprendi doctrine to invalidate statutory prohibitions. The primary basis on which the Harris plurality distinguished Harris from Apprendi was that the mandatory minimum provision only operated to limit the judge's sentencing discretion within the range of sentences already authorized by the verdict facts, in contrast to a maximum-enhancing provision that operates to exceed the sentence authorized by the verdict facts. ${ }^{254}$ Like a statute expressly imposing a specific mandatory minimum sentence, a statutory prohibition on considering age or family ties would not extend the upper limit of the sentence, but only constrain the judge's range of choices beneath that maximum. Consequently, so long as the holding of Harris remains controlling, the Court might view Harris, rather than Apprendi-Blakely, as the closer analogy to a statutory prohibition. ${ }^{255}$

253. See, e.g., Blakely v. Washington, 542 U.S. 296, 309 (2004); Apprendi v. New Jersey, 530 U.S. 466, 501, 520-22 (2000) (Thomas, J., concurring); see also Kimbrough v. United States, 552 U.S. 85, 113-14 (2007) (Scalia, J., concurring); Oregon v. Ice, 129 S. Ct. 711, 721 (2009) (Scalia, J., dissenting).

254. See Harris v. United States, 536 U.S. 545, 549-50, 556-68 (2002) (Kennedy, J., plurality opinion).

255. On the other hand, this example of the statutory prohibition illustrates why the holding in Harris has tenuous validity as the Apprendi doctrine has expanded. As the Court has increasingly expanded judicial power at sentencing at the expense of the legislature, the preservation of Harris looks more like an "exception" to Apprendi-Booker than it does a definitional component of the rule. Cf. Priester, Canine Metaphor, supra note 9, at 225-27, 261-63, 270 (criticizing Court's expansion of Apprendi-Harris into Blakely-Booker); Priester, Structuring Sentencing, supra note 10, at 904-09 (arguing that Apprendi-Harris rule is constitutionally justified). After all, if the doctrine is expanded from a rule providing that "the legislature may not mandate that judges use specific extraverdict facts to extend the upper limit on a sentence" to a rule providing that "the legislature may not mandate that judges not use specific extraverdict facts in determining a sentence," then it would seem to follow that the rule 
If the Court does expand the Apprendi doctrine into a rule excluding all legislative attempts to impose binding constraints on the exercise of judicial discretion within the sentencing range established by verdict facts, then the Court will be authorizing policy nullification in its strongest form: a judge's power to ignore express declarations of legislative sentencing policy. Once the boundaries of the judge's authority are determined, the legislature may not further constrain the judge's determination of the appropriate sentence. Alternatively stated, the legislature may implement its desired policies by using verdict facts to limit the sentencing range available to the judge-but once those limits are established, the legislature's role in sentencing is at an end.

Moreover, the rhetoric in the opinions in the Court's decisions may even imply that this constitutional proscription against constraining sentencing discretion applies not only to constraints imposed by legislatures, but also to limits on trial court discretion imposed by appellate courts through the operation of appellate review. That is, sentencing policy may be vested not merely in judges rather than legislatures, but specifically in trial court judges. The most prominent rhetoric is inherent in the definition of Booker-Rita reasonableness review laid out in Booker, Rita, and Gall: to avoid Booker violations, and to ensure that the Guidelines are truly advisory, the appellate courts are permitted to review the substantive merits of the sentence only for an abuse of discretion. ${ }^{256}$ In Gall, the Court emphasized that "[t]he fact that the appellate court might reasonably have concluded that a different sentence was appropriate is insufficient to justify reversal of the district court." ${ }^{257}$ Hence, an appellate court cannot reverse based on its view that the trial court made a flawed or unwise decision of sentencing policy; instead, it can reverse only if it concludes that the trial court's sentencing policy decision was entirely out of bounds.

Consequently, under Booker-Rita reasonableness review, appellate courts are precluded from using their powers of appellate review to enforce uniformity and consistency in

simply is "the legislature may not mandate that judges use specific extraverdict facts in determining a sentence."

256. See supra Part II.B.2.

257. Gall v. United States, 552 U.S. 38, 51 (2007). 
sentencing policy decisions by trial judges, except in the most outlying cases-this has the effect of making all but the most outrageous sentencing policy determinations by trial judges impervious to attack. The ramifications are even greater if the Court adopts Justice Scalia's position regarding asapplied challenges, maintaining appellate review also creates Apprendi doctrine violations to the extent that some sentences would only be upheld on appeal based on extraverdict facts. ${ }^{258}$ Thus, because the highly deferential standard of review of trial court sentencing decisions has constitutional moorings in the necessity of avoiding Apprendi doctrine violations, the constitutional implication for policy nullification is the same: the power rests in the hands of trial courts specifically.

An expansion of the Apprendi doctrine to constitutionalize a judicial power of policy nullification would, at its core, be nothing less than an assertion that the legislature does not have power to make sentencing policy directly-only to make offense-definition policy that constrains sentencing indirectly. Such a rule is a plausible reading of the implications of the Court's decisions to date. Whether it is a plausible reading of the Constitution is another matter.

Will the Court take the Apprendi doctrine to this full extent? It is possible, but by no means certain. Yet that path also cannot be ruled out-which is problematic enough on its own.

\section{Why Policy Nullification Is Bad Constitutional Law}

Recognition of a judicial power to engage in policy nullification at sentencing is bad constitutional law for a number of reasons. Its stronger form-allowing judges to reject express sentencing policies adopted by legislatures-is the most problematic. But even the weaker form, in which judges ignore implicit policy choices like those embedded in offense definitions, is an improper exercise of the judicial function. Nothing in the Constitution points strongly in favor of recognizing such a power, but several important constitutional values oppose it.

First is the sheer inconsistency between the power of

258. See supra Parts II.A.3 \& III.A.3. 
policy nullification at sentencing and the constitutional norms the Court otherwise insists must be applied when courts must interpret and apply issues of public policy. On matters of constitutional law, of course, the courts have claimed primacy since at least Marbury $v$. Madison. ${ }^{259}$ But on matters of non-constitutional law, the role of the courts is to interpret and apply the policies adopted by the legislature or the executive branch enforcement authorities, lest they substituted the views of unelected judges for the policy judgments of the political branches. ${ }^{260}$ Numerous decisions of the Court emphasize that the political branches are entitled to make bad policy choices, and the courts cannot overturn them absent a constitutional violation. ${ }^{261}$

When it comes to criminal sentencing, the same principles govern. The Court has heard constitutional challenges to the punishments statutorily authorized by legislatures, ${ }^{262}$ and has acknowledged that procedural due process applies to sentencing hearings. ${ }^{263}$ By contrast, the

259. See generally RONALD D. ROTUNDA \& JOHN E. NOWAK, TREATISE ON CONSTITUTIONAL LAW §§ 1.1-1.6 (4th ed. 2007).

260. See, e.g., RICHARD J. PIERCE, JR., ADMINISTRATIVE LAW TREATISE $§ 3.3$ (5th ed. 2009) (discussing the doctrine of "Chevron deference" given by federal courts to executive branch agency interpretations of statutes enacted by Congress).

261. See, e.g., Ewing v. California, 538 U.S. 11, 27-28 (2003)

To be sure, California's three strikes law has sparked controversy.

Critics have doubted the law's wisdom, cost-efficiency, and effectiveness in reaching its goals .... [But] [i]t is enough that the State of California has a reasonable basis for believing that dramatically enhanced sentences for habitual felons "advances the goals of its criminal justice system in any substantial way."

Id. (internal citations omitted).

262. Many challenges to sentences authorized by statute are made under the Eighth Amendment, see U.S. CONST. amend. VIII, which prohibits cruel and unusual punishments. See, e.g., Ewing, 538 U.S. at 11 (challenge to "threestrikes" statute); Roper v. Simmons, 543 U.S. 551 (2005) (challenge to death penalty for juvenile); Graham v. Florida, $130 \mathrm{~S}$. Ct. 2157 (2009) (granting certiorari to hear challenge to life-without-parole sentence for juvenile); Transcript of Oral Argument, Graham v. Florida, 130 S. Ct. 2011 (2010) (No. 08-7412).

263. See, e.g., United States v. Watts, 519 U.S. 148, 156 (1997) (noting that Federal Sentencing Guidelines provide for factfinding by preponderance of the evidence, and commenting that "we have held that application of the preponderance standard at sentencing generally satisfies due process.") (citing McMillan v. Pennsylvania, 477 U.S. 79, 91-92 (1986) and Nichols v. United States, 511 U.S. 738, 747-48 (1994)); Berman \& Bibas, supra note 17, at 45, 59 (noting that procedural due process applies to sentencing). 
Court has never suggested that the substantive merit of the sentence imposed on a defendant by a judge is subject to constitutional review in and of itself. Its treatment of sentencing appeals confirms this-after all, if the merits of a sentence are themselves issues of constitutional magnitude, surely the standard of review would be de novo, just as it is for other constitutional claims, rather than abuse of discretion. ${ }^{264}$ Without an issue of constitutional law in play, courts have no authority to assert the primacy of their view of appropriate policy on any particular topic. Thus, if the merits of the judge's sentencing determination are a nonconstitutional matter, then there is no constitutional justification for privileging judicial decision-making over legislative policy choices.

Similarly, vesting the power of policy nullification in trial judges is inconsistent with the ordinary constitutional norms regarding allocation of power and institutional competence. The Court has not hesitated to disclaim judicial power over areas in which courts are, due to their institutional position, suboptimal decision-makers. Classic examples include doctrines of deference to agency expertise on technical or empirical questions, or appellate court deference to trial court assessments of witness credibility. ${ }^{265}$ But this norm extends even to constitutional questions in which judges are not well suited to intervene, such as the allocation of power between the political branches in matters of foreign affairs or the jurisdictional exception of the political question doctrine. ${ }^{266}$

264. See supra note 85; Hessick \& Hessick, supra note 15, at 14 (noting that questions of law are typically reviewed de novo); id. at 26-27 (noting that policy questions typically are treated as questions of law subject to de novo review, in contrast to the deferential review applied in Kimbrough $v$. United States, 552 U.S. $85(2007))$.

265. See, e.g., PIERCE, supra note 260 , at $\S 6.9$ ("An agency with expertise in a particular area of regulation has an enormous advantage over a reviewing court in making this complicated judgment."); Salve Regina College v. Russell, 499 U.S. 225, 233 (1991)

Rule 52(a) commands that ... due regard shall be given to the opportunity of the trial court to judge of the credibility of the witnesses ... [and] we have held that deferential review of mixed questions of law and fact is warranted when it appears that the district court is better positioned than the appellate court to decide the issue in question ....

Id. (internal quotations and citations omitted).

266. See, e.g., ROTUNDA \& NoWAK, supra note 259 , at $\$ 6.3$ (judicial role in foreign affairs); id. at $\S 2.16$ (political question doctrine). 
In criminal sentencing, trial judges clearly have high competence to determine the particular facts of each case. In both Gall and Kimbrough, for example, the Court emphasized that trial judges "have an institutional advantage over appellate courts" in determining salient details about "the individual case and the individual defendant."267 And surely the Court is correct that trial judges are optimally situated to engage in the particularized and nuanced factfinding necessary to individualized punishment.

But it does not follow that trial judges also have equally high competence in taking into account concerns about systemic uniformity or in making substantive decisions about appropriate sentencing policy at the national or state level. In Gall the Court claimed that a trial judge "is in a superior position to find facts and judge their import under § 3553(a) in the individual case."268 Why is that true? The Court did not provide an explanation for its conclusion. Undeniably the sentencing judge was in the best position to determine whether Gall's offense was the product of his age and immaturity at the time. But what makes that judge better suited than an appellate court or legislature to determine how much of a discount Gall was entitled to because of those factors? Likewise, while the sentencing judge was best positioned to assess the presence or absence of Gall's family ties, it does not mean the judge was also best suited to making the systemic policy decision about the role family ties should play, if any, in calculating a sentence. Even more so in Kimbrough: how does expertise in determining the facts of a particular case have any relevance to the systemic policy decision about the appropriate punishment policy for crack and powder cocaine? Yet in Kimbrough and Spears the Court declared that district judges are entitled to make their own judgments of appropriate cocaine sentencing policy, without any acknowledgement that trial judges have a comparative institutional disadvantage in matters of systemic uniformity.

The Court's seemingly discordant perspective on policy-

267. Gall v. United States, 552 U.S. 38, 51-52 (2007) (quoting Koon v. United States, 518 U.S. 81, 98 (1996)); Kimbrough v. United States, 552 U.S. 85, 109 (2007) (quoting Gall, 552 U.S. at 51).

268. Gall, 552 U.S. at 51 (quoting Brief for Federal Public and Community Defenders et al. as Amici Curiae at 16, Gall, 552 U.S. 38 (2007) (No. 06-7949)) (emphasis added). 
making and institutional competence makes complete sense, however, when viewed in light of the analysis presented above: the Court is constitutionalizing the primacy of individualized sentencing over considerations of systemic uniformity. ${ }^{269}$ That is, if the Constitution privileges individualized punishment as the principal objective of sentencing, then it makes sense that the Court would view trial judges as the institution best situated to implement that goal. Likewise, if individualized punishment trumps systemic uniformity as a constitutional value, then the entire notion of sentencing policy at the aggregate level is marginalized. It may be true that sentencing decisions are non-constitutional decisions in the sense that a defendant lacks any constitutional basis to challenge the substantive merits of the particular sentence imposed upon him-but judicial primacy over sentencing nevertheless comes from a different constitutional source, the mandate of individualized punishment. In fact, if individualized punishment within the exclusive domain of trial judges is constitutionally required, as Justice Scalia seems to be suggesting, then "sentencing policy" essentially becomes an oxymoron because the Court would have eliminated any meaningful obligation to consider systemic factors when imposing sentence in any particular case.

Once again, as discussed above, the Court's position reveals that its underlying concern is not the identity of the factfinder but the identity of the institution holding the power to determine the normative worth of sentencing facts. ${ }^{270}$ Just as the Court's decisions protecting the trial court's discretion to calculate the sentence have nothing to do with jury power at sentencing, so too does the power of policy nullification protect judicial power over the third stage of a sentencing decision. In Rita and Gall, the Court reaffirmed the validity of judicial extraverdict factfinding at sentencing, so long as the weight carried by those facts in increasing or decreasing

\footnotetext{
269. See supra Part III.A.3; see also Bibas \& Klein, supra note 15 , at 780 ("The Court greatly weakens policy uniformity by allowing district judges to inject their own policy views."); Bowman, supra note 1, at 39 (praising "the simplicity, modesty, and rationality" of the manner in which the Washington sentencing guidelines invalidated in Blakely sought to balance systemic uniformity and individualized punishment).

270. See supra Part III.A.3.
} 
the sentence, respectively, is decided by the judge. In both cases the Court emphasized that the judge takes into account the advice of the Guidelines about which facts to find and how much they are worth, but is not compelled to impose the sentence recommended by them. The same is true in the context of policy nullification. In Kimbrough, both the district judge and the Court agreed with the Guidelines that the quantities of crack and powder cocaine were facts relevant to punishment, and the Court ratified the district judge's decision to assign a far lower weight to the crack quantity than the Guidelines recommended. Similarly, a statute prohibiting a judge from relying upon age or family ties in calculating a sentence has the effect of assigning a mandatory weight of zero to those facts, precluding the judge from increasing or decreasing the sentence based upon finding them. If the stronger form of policy nullification were used to deem such a statute unconstitutional, it would be because the statute unconstitutionally interferes with the judge's power to determine the normative worth of sentencing facts.

The problem, of course, is that the Constitution does not adopt a single approach to sentencing, nor does it entrench the supremacy of one sentencing perspective over the other. Certainly, the determination of the specific sentence to be imposed in a particular case has nothing to do with the Jury Trial Clause. Justice Alito had it exactly right in Gall, writing that "[w]hat is at issue, instead, is the allocation of the authority to decide issues of substantive sentencing policy, an issue on which the Sixth Amendment says absolutely nothing."271 No other provision of the Constitution commands exclusive judicial power over sentencing, either, and neither the separation of powers nor the constitutional structure of criminal procedure can justify it. In the end, then, policy nullification is simply yet another example of the Court's misguided approach to the constitutional law of sentencing, and the illegitimate judicial power-grab at the

\footnotetext{
271. Gall, 552 U.S. at 64 (Alito, J., dissenting); see also id. at 66. A sentencing system that gives trial judges the discretion to sentence within a specified range . . . also gives individual judges discretion to implement their own sentencing policies. This latter feature, whether wise or unwise, has nothing to do with the concerns of the Sixth Amendment, and a principal objective of the Sentencing Reform Act Id. was to take this power out of the hands of individual district judges.
} 
core of the doctrine it has developed.

\section{Correcting Course: Fixing the Court's Errors in the} Apprendi Doctrine

With all of these profound problems afflicting the Court's version of the Apprendi doctrine, the need for a course correction is apparent. Fortunately, a solution is available that will eliminate the deep flaws in the Court's approach without voiding wholesale the Court's rightful concern about the need for some constitutional law of sentencing.

The Court can solve the problems in the Apprendi doctrine by restoring the doctrine to its roots in ApprendiHarris and abrogating the expansions it has imposed atop the core Apprendi principle. The doctrine's foundation in Apprendi is important, and it is easily constitutionally justified. When verdict facts are established, those facts are the only ones that can constitutionally be used to determine the offense of conviction. Consequently, the Court was correct in Apprendi to hold that the verdict facts must be mapped over to the offense-defining statutes in determining the maximum punishment authorized for those facts by those statutes. ${ }^{272}$ The use of extraverdict factfinding to exceed the maximum sentence available for the verdict facts is likewise unconstitutional precisely because it is contrary to the constitutional structure of criminal procedure by allowing punishment as though the defendant had been convicted for a greater offense of which he was not actually convicted. ${ }^{273}$ When the Apprendi doctrine is limited to this basic principle, it serves important constitutional values without producing absurd formalisms and unjustified judicial power-grabs.

This solution also requires, therefore, that the Court overrule its Blakely-Booker expansion of the Apprendi doctrine and the corresponding remedial ramifications under Booker-Rita reasonableness review. That is where the Court has gone astray, by extending to sentencing-regulating provisions a constitutional doctrine necessary to enforce the constitutional structure of criminal procedure with respect to offense-defining statutes. The Court should reverse this extension, and restore the new constitutional law of

272. Priester, Structuring Sentencing, supra note 10, at 873-76.

273. Id. at 896-902; Priester, Canine Metaphor, supra note 9, 230-31. 
sentencing to its original scope, ${ }^{274}$ enforcing the line between offense-defining and sentencing-regulating provisions, but not prohibiting the use of the latter. For similar reasons, the Court should reject Justice Scalia's call to expand the doctrine further to encompass as-applied challenges, especially to the extent his position constitutionalizes deferential appellate review of sentencing decisions by trial judges. So long as the verdict facts determine the offense of conviction, and the ultimate sentence imposed is within the boundaries delimited by that offense, the Court should hold that the use of mandatory sentencing-regulating provisions to restrict the judge's discretion in calculating that sentence does not violate the Constitution. ${ }^{275}$

The consequences of this course correction would be to restore the constitutionality of the various forms of sentencing laws that the Court had invalidated. The Federal Sentencing Guidelines could, for example, once again be enforced with mandatory effect; so could similar state sentencing regimes, and related state systems like presumptive sentences or upper- and lower-term sentencing ranges. Similarly, appellate review would not be constrained to abuse of discretion, but could be de novo or another substantially less deferential standard. Most of all, the course correction would once again allow the fifty states to experiment with numerous variations on the full range of sentencing-regulating provisions, from trial court discretion with deferential appellate review to mandatory sentencing guidelines with de novo review, and everything in between. Given the wide range of normative and empirical disagreements about what constitutes the wisest, fairest, and most effective sentencing policy, it is difficult to see why this wide latitude for state experimentation would not be a

274. See Priester, Structuring Sentencing, supra note 10, at 896-910; Priester, Canine Metaphor, supra note 9, at 301-08. Professor Bowman argues for a similar position: "[T] he Court should acknowledge that some reasonable legislative guidance of judicial sentencing discretion is constitutionally legitimate and practically beneficial and devote its future energies to the task of maintaining a reasonable balance between legislative, judicial, executive, and citizen jury control over sentencing outcomes." Bowman, supra note 1 , at 99 .

275. Professor Bowman suggests that the Court should continue to impose some limits on the use of mandatory sentencing-regulating provisions, but argues that the constitutional source for such limits should be the Due Process Clause, rather than the Sixth Amendment. See Bowman, supra note 1, at 9194. 
salutary development.

Similarly, if the Court were to reverse course with its expansions of the Apprendi doctrine, then the potential implications of overruling Harris become far less severe. The constitutional structure of criminal procedure supports preserving the holding of Harris: once the verdict facts have established the outermost, worst-case scenario for punishment, then the defendant has no constitutionally cognizable entitlement to any particular merciful sentence less than that maximum, and therefore the use of extraverdict factfinding to determine the precise sentence is constitutionally permissible. ${ }^{276}$ A majority on the current Court may see the issue differently, though, reasoning that the verdict facts should determine both the defendant's worstcase and best-case scenario for punishment. ${ }^{277}$ Once the Court has corrected course and limited the scope of the Apprendi doctrine to simply Apprendi itself, then overruling Harris would not be problematic. If the doctrine only applies to the sentencing constraints imposed by offense-defining statutes, then overruling Harris would have the effect of requiring only that the mandatory minimum sentences included within offense-defining statutes be triggered by verdict facts. Other mandatory increases in the low end of the available sentence, such as sentencing guidelines calculations or statutory sentencing-regulating provisions, would remain subject to extraverdict factfinding.

Finally, the Court should, of course, correct the Apprendi doctrine by making clear that the Constitution does not codify any particular balance between the objective of imposing individualized punishment for each defendant on the one hand, and the objective of systemic uniformity in the consideration of sentencing facts and their normative weight on the other. That balance is a highly controversial and hotly contested issue, and it is one on which constitutional law ought to remain silent. Aside from permitting the legislature to resolve such a disputed question of sentencing policy,

276. Priester, Structuring Sentencing, supra note 10, at 902-09 (arguing that the constitutional structure of criminal procedure supports the decision in Harris).

277. See supra notes 62-70 \& 150-152 and accompanying text (discussing Harris v. United States, 536 U.S. 545 (2002)). Professor Bowman argues for overruling Harris for this reason. See Bowman, supra note 1, at 16-21, 34-37. 
removing constitutional obstacles to striking the balance also would facilitate even more experimentation in sentencing regimes among the states. Leaving more options on the table will, in the long term, likely produce far more insights into fair and effective sentencing policy than foreclosing numerous avenues as a matter of constitutional law.

\section{CONCLUSION}

The time has come for the Court to acknowledge the numerous serious problems with its new constitutional law of sentencing, and to correct course by bringing the doctrine back to its foundational principles. The Court should restore the Apprendi doctrine to its core purpose of preserving the integrity of the verdict facts and ensuring that the punishment imposed on the convicted defendant is consistent with the sentence authorized by the offense of conviction. Beyond that, however, the Court should abrogate its expansions of the doctrine. By doing so the Court would eliminate the absurd formalisms embedded in the current doctrine and the perverse incentive for sentencing judges to be more arbitrary and less transparent in their reasoning when determining punishment. The retrenchment of the Apprendi doctrine also would place the constitutional law of sentencing on sound conceptual footing in the constitutional structure of criminal procedure, rather than solely in the illegitimate protection of judicial power.

Finally, the Court should disclaim any constitutional mandate for the authority for sentencing judges to engage in "policy nullification" when they reject legislatively adopted sentencing policies in favor of the judges' own policy preferences, whether those policies are contained in the implicit spirit of the law or express declarations of sentencing policy enacted in statutes. Instead, the Court should recognize that decisions of non-constitutional sentencing policy rightfully belong to legislatures. Even when faced with bad legislative policy judgments, the solution should not be the Court's bad constitutional law. Otherwise, criminal sentencing may be lost in Bizarro World for years to come. 